\title{
Exploring the Stony Coral Tissue Loss Disease Bacterial Pathobiome
}

\section{RUNNING TITLE: SCTLD Bacterial Pathobiome}

\author{
Iwanowicz, D.D. ${ }^{1}$, W.B. Schill ${ }^{1}$, C. M. Woodley ${ }^{2}$ A. Bruckner ${ }^{3}$, K. Neely ${ }^{4}$, and K.M. Briggs ${ }^{1}$ \\ ${ }^{1}$ U.S. Geological Survey, National Fish Health Research Laboratory, 11649 Leetown Road, \\ Kearneysville, WV 25430 \\ ${ }^{2}$ National Oceanic and Atmospheric Administration, National Ocean Service, National Centers \\ for Coastal Ocean Science, 331 Fort Johnson Rd., Charleston, SC 29412 \\ ${ }^{3}$ National Oceanic and Atmospheric Administration, Florida Keys National Marine Sanctuary, 33 \\ East Quay Road, Key West, FL 33040 \\ ${ }^{4}$ NOVA Southeastern University \\ 3301 College Avenue, Fort Lauderdale, FL 33314
}

USGS disclaimer: This draft manuscript is distributed solely for purposes of scientific peer review. Its content is deliberative and predecisional, so it must not be disclosed or released by reviewers. Because the manuscript has not yet been approved for publication by the U.S. Geological Survey (USGS), it does not represent any official USGS finding or policy.

Any use of trade, product, or firm names is for descriptive purposes only and does not imply endorsement by the U.S. Government.

*Corresponding Author: Address correspondence to William B. Schill, wschill@usgs.gov KEY WORDS: microbial community, SCTLD, coral, MiSeq, 16S rRNA 
1 ABSTRACT A devastating novel coral disease outbreak, referred to as Stony Coral Tissue Loss

2 Disease (SCTLD), was first described in 2014. It is thought to have originated offshore of Miami-

3 Dade County, FL, but has persisted and spread, affecting new reefs along the Florida Reef Tract

4 and reefs of at least 8 other Caribbean jurisdictions. We investigated the microbial communities

5 of clinically normal and diseased specimens of five species of affected corals using targeted 16S

6 ribosomal DNA sequencing (Illumina MiSeq). Fifty-nine bacterial sequences were identified

7 using contrast analysis that had enriched abundance in diseased coral host microbiomes

8 relative to the microbiomes of clinically normal hosts. Several sequences from known bacterial

9 pathogens were identified in this group. Additionally, we identified fifty-three bacterial species

that had differentially elevated numbers in clinically normal coral host samples relative to

11 samples from diseased host corals. The bacterial consortia composing the clinically normal and diseased coral microbiomes were clearly distinct taxonomically. Predicted functional profiles based on taxonomy, however, were found to be quite similar. This indicates a high level of functional redundancy among diseased and clinically normal microbiome members. Further examination of the direct sequencing data revealed that while some bacteria were differentially distributed according to disease status, others were not. Fifty-one bacterial species were found in both diseased and clinically normal coral host samples and not differentially abundant in either disease state. These still may be important in explaining the presentation of disease.

IMPORTANCE Determining causation is a management top priority to guide control and intervention strategies for the SCTLD outbreak. Towards this goal we examined bacterial taxa that were differentially elevated in numbers in diseased corals as compared to clinically normal 
23 corals at Looe Key, FL in August 2018. Many of the bacterial species we detected are known to

24 be pathogenic to humans, animals, and (or) plants, and some of these have been found

25 associated with diseased corals in other studies. Microbes that were present (or conspicuous by

26 their absence) in both diseased as well as clinically normal corals were also examined because

27 "healthy" corals from a diseased location such as Looe Key may have been exposed but may not

28 have been showing overt disease at the time of sampling. Although untangling of causation is

29 not possible currently, certain bacterial cliques and excess nutrients appear to be potential risk

30 factors in SCTLD pathology. 
32 Stony coral tissue loss disease (SCTLD) is a newly emerged lethal disease that has been affecting scleractinian corals along the Florida Reef Tract (FRT) since 2014. With white plaguelike signs (https://nmsfloridakeys.blob.core.windows.net/floridakeys$\mathrm{prod} / \mathrm{media} / \mathrm{docs} / 20181002$-stony-coral-tissue-loss-disease-case-definition.pdf), this disease outbreak was first recorded at Virginia Key near Miami $(1,2)$. By the winter of 2015, the disease had spread to the northern area of the Upper Keys within the Florida Keys National Marine Sanctuary. In 2016 and 2017 the disease spread north through Martin County and south through the Upper Keys (2). Between 2014-2015, SCTLD was found by W. F. Precht et al. (1) to spread at a rate of $2.5-5 \mathrm{~km}$ per month, but this rate of disease advancement apparently increased to $8-22 \mathrm{~km}$ per month in $2017-2018$ as noted by K. Neely (3). In 2018, researchers were observing corals infected with SCTLD in the Middle Keys, and by December of 2019 corals infected by SCTLD were found well south of Key West and into the Marquesas Keys. Though originating in Florida, signs of SCTLD were recognized in Jamaica in 2017 and the disease now

45 has been reportedly observed or suspected in the Mexican Caribbean, St. Maarten, the U.S.

46 Virgin Islands, the Dominican Republic, the Turks and Caicos, Belize, the Netherlands Antilles, 47 Puerto Rico, and the Bahamas (2). SCTLD has been found to affect more than 20 of the 45 Caribbean reef-building coral species (stony corals), does not seem to be self-limiting as in the case of some other diseases, and does not seem to slow in cooler seasons (2). The affected species include four of seven

51 Caribbean species that are listed as threatened (Federal Register 2006, 2014) under the

52 Endangered Species Act of 1973 and have been further categorized as either highly susceptible, 53 intermediately susceptible, presumed susceptible, and low susceptible species. The disease 
54 causes rapid mortality among affected coral species, with a high rate of transmission and it has

55 affected a large geographic range over the more than six years it has been spreading (2). It is

56 interesting to note that neither Acropora palmata nor A. cervicornis show susceptibility to

57 SCTLD. As most reported coral diseases have low prevalence $(<5 \%)$ and are not considered

58 contagious (1), this multi-year outbreak is somewhat of a unique phenomenon. The gross

59 morphological characteristics of the disease can vary among sites and species. Tissue loss often

60 appears basally, peripherally or both on a colony and spreads upward leaving intact white

61 skeleton (indicative of the rapid tissue loss) before algal colonization follows within 3-7 days.

62 Tissue loss lesions can also present as patches within intact tissue that increase in size, often

63 fusing into larger denuded areas. Histologically, the lesions appear first along the basal body

64 wall then progress upward to envelop the rest of the polyp (J. H. Landsberg, unpublished data;

68 include water pollution, habitat destruction, overfishing, invasive species, global climate

71 intervention actions to halt or minimize impacts. Interventions including treatment of diseased

72 colonies with specific antibiotics have been shown to retard or stop the tissue loss suggesting

73 bacterial involvement in the disease etiology (6-11). The similar disease presentation and

74 response to treatment across many coral species suggests that the same causative agent(s) are

75 at work with limited variation among coral hosts. 
Metagenomic sequencing of the 16S rRNA gene has been widely used to study the

77 bacterial composition of multiple and varied sample types, most notably perhaps, the human

78

79

80

82

83

84

85

86

87

88

microbiome (12-15). Increasingly however, metagenomic studies have been made on an ever

broadening array of environmental microbial consortia including those associated with plants, animals, water, and sediment (16-19) as well as those associated with corals (20-25).

The aim of this study was to identify possible causative agents for SCTLD that have been affecting the Florida Reef Tract since 2014. We report here the bacterial consortia associated with five SCTLD-susceptible coral species (FIG 1) collected from Looe Key, FL in 2018 during an active outbreak. Direct, high throughput $16 \mathrm{~S}$ amplicon sequencing (Illumina MiSeq) was used to determine if or how microbial communities differ between clinically normal and diseased corals.

\section{RESULTS}

We performed 165 sequencing of the bacterial consortia associated with diseased and clinically normal specimens of five important species of Caribbean stony corals affected by SCTLD to identify potential causative agents. A total of $10,081,496$ sequence reads passed quality filtering with $6,410,207$ of these classified by the One Codex platform at the species level and 1,546 total bacterial species were identified in the diseased coral samples. Bacterial species detected in the clinically normal coral samples totaled 1,981. After trimming uninformative species classifications with the lowest read assignments (lower 0.25\%), 1,119 and 1,407 species classifications remained from the diseased and clinically normal samples, respectively. Remaining sequence assignments for all libraries numbered minimally 96 to 1,961 
depending on the host sample (Table 2). Thus, the classifications retained for further analyses were those that were observed a reasonable number of times.

Diversity analyses. We examined the distribution of genetic diversity within samples (alpha diversity) as well as among disease states (beta diversity). Alpha diversity measures (Simpson; FIG 2) were somewhat variable for some species and (or) disease state replicates, but these variations were not statistically significant among the coral host microbiomes that were tested regardless of host species and (or) disease status. The Mann-Whitney test yielded a pvalue of 0.84211 for the comparison of diseased versus clinically normal alpha diversity values, and evaluation of differences in alpha diversity among coral species sampled using KruskalWallis testing yielded a p-value of 0.50768 . In contrast, beta diversity analysis of JensonShannon divergence measures using ANOSIM demonstrated that the microbes associated with the diseased and clinically normal states were of quite different composition (FIG 3).

Distribution of bacterial taxa across coral species and according to disease state. The distribution across host corals of the most commonly identified bacterial species are shown in Tables 3 and 4. Two species of Achromobacter and three species of Fulvivirga were common among the clinically normal coral microbiomes (Table 3) and Achromobacter xylosoxidans was universally present. Two species of Arcobacter were common among the diseased coral microbiomes with Arcobacter bivalviorum being a member of all diseased microbiome libraries as were Algicola bacteriolytica and Clostridioides difficile. Contrast analysis using edgeR revealed fifty-nine bacterial species that were enriched in abundance in diseased coral host samples relative to clinically normal hosts and are shown in Table 5. Fifty-three bacterial species had differentially elevated numbers in clinically normal coral host samples relative to 
diseased host corals (Table 6), while fifty-one bacterial species were found in both diseased and clinically normal coral host samples and not differentially abundant in either disease state (Table 7). All the taxa listed in Table 3 were found to be present in clinically normal as well as diseased samples (Table 7) except for Fulvivirga kasyanovil, found only in clinically normal samples (Table 6). All the taxa listed in Table 4 were found to be among those elevated in diseased coral samples (Table 5) except for Arcobacter sp. UDC415 and "Candidatus Amoebophilus asiaticus" that were present in both clinically normal and diseased coral samples (Table 7). Some bacteria known from other studies to be generally abundant and associated with a wide variety of corals and other marine invertebrates (22) were rare in the Looe Key coral microbiomes. Ruegeria spp., for example, were relatively low in abundance and restricted to the clinically normal samples (Table 6). Endozoicomonas species abundances in clinically normal coral samples were found to be $0 \%$ in C. natans and $D$. labyrinthiformis, $0.186 \%$ in $D$. stokesii, $0.013 \%$ in 0 . annularis, and $1.604 \%$ in P. strigosa. Endozoicomonas in diseased coral samples was only detected in 0 . annularis at an abundance of $0.582 \%$.

Inferred expression of major gene groupings. The inferred expression levels of the Kyoto Encyclopedia of Genes and Genomes (KEGG) major gene groupings including amino acid metabolism, biosynthesis of secondary metabolites, carbohydrate metabolism, energy metabolism, glycan biosynthesis and metabolism, lipid metabolism, metabolism of cofactors and vitamins, metabolism of amino acids, metabolism of terpenoids and polyketides, nucleotide metabolism, and xenobiotics biodegradation and metabolism were similar regardless of disease status and microbiome composition (FIG 4). Thus, major functionalities of 
141 the members of the clinically normal coral microbiomes are also present in equivalent numbers

142 in the diseased coral microbiomes.

\section{DISCUSSION}

Stony Coral Tissue Loss Disease (SCTLD) is one of the more severe problems to confront Florida and Caribbean reefs in the $21^{\text {st }}$ century, potentially causing significant loss to ecosystem services and impacting economies. This outbreak is unusual due to its extended duration, apparent highly contagious nature, range of coral species affected, and rate of progression

149 (https://floridakeys.noaa.gov/coral-disease/). Based on reports that amoxicillin can arrest tissue

loss progression in several species, a number of researchers have focused on microbiome

151 analyses to identify potential causative agents. J. L. Meyer et al. (25) recently reported

152 identifying five amplicon sequence variants that were higher in abundance in diseased as

153 opposed to healthy specimens of Montastraea cavernosa, Orbicella faveolata, Diploria

154 labyrinthiformis and Dicocoenia stokesii. The identified amplicon sequence variants were found

155 to be from an unclassified genus of Flavobacteriales, sequences identified as Fusibacter

156 (Clostridiales), Planktotalea (Rhodobacterales), Algicola (Alteromonadales), and Vibrio

157 (Vibrionales). The authors also identified opportunistic or saprophytic colonizers including 158 Epsilonbacteraeota, Patescibacteria, Clostridiales, Bacteroidetes, and Rhodobacterales that 159 were also found to be enriched in SCTLD disease lesions. 
163 (25) and more recently those of S. M. Rosales et al. (26) were obtained using a cluster first

164 approach. Although both strategies are widely used, each has pros and cons (27). Nevertheless,

165 many of the findings of the two studies have general similarities regarding taxa identified as

166 differentially elevated in numbers in diseased host corals. Sequence classifications that we

167 obtained from the clinically normal coral samples were found to represent mostly bacterial

168 species often found in coastal marine environments. In contrast, we found that several

169 differentially abundant sequence classifications obtained from the diseased coral samples

170 relate to bacteria with known pathogenic potential. Particularly notable are those that are

171 common in specimens with active disease signs across the five coral species studied and that

172 are relatively high in abundance. These include, but are not limited to, Clostridioides difficile,

173 Romboutsia lituseburensis, Arcobacter bivalviorum, Algicola bacteriolytica, Vibrio sp. r24,

174 Shimia aquaeponti, Burkholderia gladioli, and Pseudoalteromonas haloplanktis (Tables 4 and

175 5). In fact, Clostridioides difficile, Arcobacter bivalviorum, and Algicola bacteriolytica were found

176 without exception in every diseased coral specimen. Burkholderia gladioli, usually a plant

177 pathogen, produces several inhibitory and (or) toxic substances, among them gladiolin,

178 bongkrek acid, enaxyloxin, and toxoflavin which can be fatal to humans. It is unknown if these

179 toxins affect corals and (or) lower vertebrates. The presence of Clostridioides difficile,

180 Romboutsia lituseburensis and other species often associated with soil, human, and animal gut

181 consortia may implicate surface runoff and (or) fecal contamination as a contributing factor to

182 SCTLD.

Bacterial taxa found not to be differentially elevated in abundance according to

disease state. In addition to the bacterial species found to be differentially elevated in 
abundance according to disease state, some prominent species' numbers were found to be relatively constant regardless of disease state, and therefore their function(s) as microbiome members are important to consider. Achromobacter xylosoxidans, Achromobacter denitrificans, Prosthecochloris vibrioformis, and "Candidatus Amoebophilus asiaticus" were in this class as were several species of Halodesulfovibrio. Achromobacter xylosoxidans has been identified as an amoeba-resistant bacterium (ARB) in several studies $(28,29)$. Many free-living amoebas including Acanthamoeba, Dictyostelium, Hartmannella, and Naegleria can harbor bacteria (30, 31). ARBs have defense mechanisms that allow them to avoid ingestion or to survive in amoeba and other protists intracellularly and multiply. They may even persist through the resting cyst stage of the amoebae. Bacteria that can survive within amoebae gain protection from environmental insults from their amoeboid host $(28,32,33)$. Because the survival mechanisms possessed by ARBs are similar to traits required for survival during infection of higher eukaryotes, ARBs are often found to be pathogenic $(28,29,34-37)$.

"Candidatus Amoebophilus asiaticus" has been found widely in Caribbean corals (22) and was found to be among the dominant members of both the clinically normal and diseased Looe Key coral microbiomes sampled. Although it is an obligate endosymbiont of Acanthamoeba of the T4 grouping, it has not been possible to transfer it to other amoeba to date (38). This potentially indicates that this microbe is not widely amoeba-compatible or that its primary host may be something other than amoebae. Analysis of the genome of " $\mathrm{Ca}$. Amoebophilus asiaticus" (39) revealed that it shares eukaryotic domains that are significantly enriched in the genomes of other intracellular parasitic bacteria (including chlamydiae, Legionella pneumophila, Rickettsia bellii, Francisella tularensis, and Mycobacterium avium). 
207 Thus, these diverse bacteria appear to exploit common mechanisms for interaction with their

208 hosts. It is not clear if "Ca. Amoebophilus asiaticus" is internal to coral-associated free-living

209 amoebae, or if the bacterium infects coral amoebocytes (40). If internal, the parasitic nature of

210 this microbe might predispose corals to biotic and abiotic disease. If other amoeba-resistant

211 bacteria that are present in high abundance (i.e. Achromobacter sp. as shown by amoeba co-

212 culture) are also intracellular, the combination could be further debilitating. Amoebae are

213 considered "training grounds" for bacterial pathogens and "Ca. Amoebophilus asiaticus" has an

214 impressive number of insertion sequences in its genome (39) as does Achromobacter (41-43)

215 making horizontal gene transfer and dissemination of virulence elements very possible in the

216 confinement of intracellular space.

Endozoicomonas, another taxon that is known to be endosymbiotic, can be dominant in

many coral and marine invertebrate species (44-47) achieving abundances as high as $85 \%$ (40,

44). Endozoicomonas is known to be capable of intracellular as well as free-living lifestyles, is

sensitive to dysbiosis of the microbiome, and is diminished in intracellular numbers under

unfavorable conditions. Endozoicomonas spp. are generally thought to be associated with

222 healthy hosts $(22,48)$, but exhibit multiple relationships with their hosts, transitioning through

223 symbiotic, mutualistic, and parasitic roles opportunistically (46). This endosymbiont has been

224 thought to provide for metabolism of dimethylsulfoniopropionate (DMSP; (49-53) but genes

225 for processing of DMSP were not identified in sequenced species $(45,46)$. Recently, however, $\mathrm{K}$.

226 Tandon et al. (54) have identified a dominant coral bacterium, Endozoicomonas acroporae that

227 does metabolize DMSP. Other than DMSP processing, this endosymbiont is thought to provide

228 benefit to the host including nutritional functions (55), antimicrobial functions (56), and 
229 functions associated with algal symbiont interactions $(44,57)$. Interestingly however,

231 abundances (less than 1.6\%) in the bacterial consortia of multiple coral species at Looe Key

232 regardless of disease state may be an indication that the "clinically normal" corals were

233 stressed and (or) infected but not showing overt disease at the time of sampling. Disease and

234 mortality continued unabated throughout 2018 as SCTLD moved southward along the Florida

235 reef tract.

Potential nutrient influence on affected coral microbiomes. Sewage contamination and

surface runoff has long been recognized as problematic for coral health (5). V. N. Bednarz et al. exposure to nutrient-rich conditions leads to dysbiosis and disease development. Another study

241 has examined the impacts of land-based sources of pollution on the microbiota of Southeast

242 Florida coral reefs and found that the major influence was from sewage outfalls adjacent to

243 reef tracts, but that runoff from inlet outfalls was substantial as well (61). B. E. Lapointe et al.

244 (62) have recently reported on a three-decade study of nitrogen enrichment at Looe Key and

245 found a connection with reef decline. Nutrient levels can also modulate parasitic infections as

246 shown by J. G. Klinges et al. (63) who have recently identified a marine invertebrate-associated

247 Rickettsiales parasite that the authors found is encouraged by nutrient enrichment to overgrow

248 and weaken and (or) kill the host coral cells it infests. 
251 Prosthecochloris vibrioformis, found in great abundance in all our coral specimens, is a strictly

252 anaerobic green sulfur endolithic bacterium that has nitrogen assimilation and reduction

253 pathways and produces proline in nitrogen rich environments (64). Proline has been found to

254 be essential for the growth of $C$. difficile as well as other pathogens (65). C. difficile is a strict

255 anaerobe that would be expected to locate in coral anoxic zones such as in the skeleton or at

256 the skeletal-tissue interface. C. difficile produces toxins and is also known to produce para-

257 cresol ( $p$-cresol), a compound that is inhibitory to many Gram-negative bacteria that is thought

258 to play a role in the ability of $C$. difficile to colonize tissues (66). An abundant species that we

259 found ubiquitous in our coral specimens, Achromobacter xylosoxidans, can degrade p-cresol via

260 p-cresol methylhydroxylase (67) unlike many other Gram- negative bacteria and would be

261 immune to the effects of p-cresol. Additionally, although Achromobacter xylosoxidans is

262 generally classified as aerobic, it can function anaerobically via denitrification (41). Clostridia

263 have been found to be present in high abundance in coral skeleton and Prosthecochloris

264 vibrioformis is dominant in stony corals due to the density of their skeletons providing a very

265 anaerobic environment (64). Thus, it is possible that excess nutrients fuel Prosthecochloris

266 vibrioformis growth and nitrogen fixation that subsequently supports Clostridioides difficile

267 colonization, growth, and coral tissue damage via toxin production. The production of toxins at

268 the tissue-skeletal interface may explain the observation that SCTLD pathology first affects the

269 basal body wall of the coral polyps.

Taxonomic redundancy. Finally, we tested to what degree members of the clinically

271 normal and diseased coral microbiomes had similar inferred functionality profiles. Beta

272 diversity analysis demonstrated that the microbes associated with the two disease states were 
273 quite different. The inferred expression of major gene groupings for these two groups,

274 however, was similar regardless of disease status and microbiome composition. This result is

275 similar to that found in other complex microbiomes including the human gut (13) and the algae,

276 Ulva $(17,68)$ and reveals the redundancy of metabolic potential in coral-associated bacteria

277 and the fluidity of specific bacterial species membership in the microbiomes of clinically normal

278 and diseased stony corals.

Conclusion. While disease outbreaks are not uncommon, this event is unique due to its large geographic range, extended duration, rapid progression, high rates of mortality and the

281 number of species affected. The disease is thought to be caused by bacteria and can be

282 transmitted to other corals through direct contact and water circulation (11). This study reveals

283 the bacterial component of SCTLD specifically at a place and a time associated with a disease

284 that is moving rapidly both geographically and temporally (69). Our inferences are made based

285 on the abundance of bacterial sequences in diseased versus clinically normal states. Abundance

286 is not an unequivocal measure of causality, however. It is possible that some rare, but

287 influential bacterium somehow triggers remodeling of the coral microbiome $(70,71)$ given the

288 variety of interactions among coral-associated bacteria (72). The redundancy of the microbiome

289 members functional repertoire observed in this study as well as others (73) suggests that the

290 makeup of the coral microbiome is a rather fluid thing influenced by space, time and abiotic

291 factors. The dysbiosis generated from transient membership changes and microbiome

292 remodeling in response to environmental circumstances may result in bacterial cliques being

293 formed that collectively exhibit properties that have pathological implications for the host. 
296 is tempting to conjecture, given the evidence presented here for example, that microbial

297 endoparasites (such as "Ca. Amoebophilus asiaticus") may predispose Caribbean corals to

298 infection by opportunistic pathogens normally held at bay by a healthy microbiome including

299 beneficial endosymbionts such as Endozoicomonas or that Clostridioides difficile introduced by

300 terrestrial or surface runoff and fueled by excess nutrients may reside in the anoxic zone at the

301 skeletal-tissue interface and produce the histopathological effects observed with SCTLD.

There may not be a single specific pathogen that causes SCTLD, but rather a have identified a relatively short list of bacteria associated with SCTLD pathology. Our findings and (or) metabolomic approaches may help to identify universal pathogenic mechanisms that operate regardless of the exact microbiome composition.

\section{MATERIALS AND METHODS}


315 December 31, 2018. Duplicate specimens from actively diseased and clinically normal coral

316 colonies were collected from Orbicella annularis (OANN), Diploria labyrinthiformis (DLAB),

317 Colpophyllia natans (CNAT), Pseudodiploria strigosa (PSTR), and Dichocoenia stokesii (DSTO)

318 except for $D$. labyrinthiformis for which we had only one clinically normal specimen ( $\mathrm{n}=19$ total

319 specimens). Coral specimens were collected in the 2-5 meter depth range on scuba using

320 hammer and clean chisels to collect fragments. Fragments were placed in zippered plastic bags

321 for transport to the surface. Each of the coral specimens was placed into a separate 5-gal

322 bucket filled with local natural seawater and covered with a lid. These samples were

323 transported (approximately $1.5 \mathrm{~h}$ ) to the Everglades National Park, Florida Bay Interagency

324 Science Center (FBISC) in Key Largo, Florida for subsampling and processing. Samples were

325 processed for metagenomic sequencing of bacterial suspensions from coral tissue

326 homogenates. A subsample (approximately $3.25 \mathrm{~cm}^{2}$ ) that included tissue and skeleton from

327 the disease margin of affected specimens or clinically normal specimens was aseptically

328 removed and homogenized in a pre-sterilized mortar and pestle by grinding the tissue section

329 in $2 \mathrm{~mL}$ of filter-sterilized artificial seawater (Instant Ocean Spectrum Brands, Blacksburg, VA)

330 into a slurry. The homogenates were transferred into $2 \mathrm{~mL}$ sterile microcentrifuge tubes and

centrifuged at $180 \times g$ for 10 min to remove cellular debris. The supernatants $(1 \mathrm{~mL})$ containing

332 bacteria were then recovered, bacteria were pelleted at $10,000 \times \mathrm{g}$ for $5 \mathrm{~min}$, and the pellets

333 were resuspended in $800 \mu \mathrm{L}$ DNA/RNA Shield (Zymo Research, Irvine, CA) and frozen until DNA

334 was extracted and used for direct 165 amplicon sequencing. 
337 Quick-DNA Fecal/Soil Microbe Miniprep Kit (Zymo Research, Irvine, CA). All extracted DNA was

338 stored in the supplied kit elution buffer at $-20^{\circ} \mathrm{C}$ until polymerase chain reaction (PCR) was

339 performed. Negative controls included kit reagent and field blanks. Positive controls were

340 provided by extracts of a ZymoBIOMICS Microbial Community Standard (D6300; Zymo

341 Research, Irvine, CA). Bacteria were characterized using PCR that targeted the V3 and V4

342 portion of the 16S rRNA gene to amplify that gene segment for subsequent Illumina MiSeq

analysis. Amplicons were produced in two steps, first using rRNA-specific primers (see below) to

generate a high concentration of input template followed by less efficient fusion primers that

incorporate exogenous sequencing adapters. Oligonucleotide primers for the V3-V4 16S rRNA

gene region $(74,75)$ were used to create a single amplicon of $\sim 460$ base pairs (bp). The primers

347 for the first amplification reaction were 16S Forward (5' - CCTACGGGNGGCWGCAG $\left.-3^{\prime}\right)$ and

16S Reverse (5' - GACTACHVGGGTATCTAATCC - 3') (74, 76). Cycling parameters were: initial

denaturation for $3 \mathrm{~min}$ at $95^{\circ} \mathrm{C}$, followed by 35 cycles of $30 \mathrm{~s}$ at $95^{\circ} \mathrm{C}, 30 \mathrm{~s}$ at $55^{\circ} \mathrm{C}$, and $30 \mathrm{~s}$ at

$72^{\circ} \mathrm{C}$, followed by a final extension at $72^{\circ} \mathrm{C}$ for $7 \mathrm{~min}$. Amplicon size was confirmed by agarose

351 gel electrophoresis using $5 \mu \mathrm{L}$ of the reaction product. PCR products were cleaned with the

352 Qiagen PCR Purification Kit (Valencia, CA) and quantified using a Qubit fluorometer (dsDNA HS

353 Assay Kit, ThermoFisher Scientific, Grand Island, NY). Samples were diluted in 10 mM Tris buffer

$354(\mathrm{pH} 8.5)$ to a final concentration of $5 \mathrm{ng} / \mu \mathrm{L}$. Using the $16 \mathrm{~S}$ rRNA primers modified with the

355 sequencing adaptors specified in Illumina's 16S Metagenomic Sequencing Library Preparation

356 (CT \#: 15044223 Rev. B), amplicon libraries were prepared following the manufacturer's

357 protocol. Each sample was indexed with Illumina's Nextera XT multiplex library indices, which

358 incorporates two distinct 8 bp sequences on each end of the fragment. Libraries were 
quantified fluorometrically, as above. DNA size distribution was determined with an Agilent

2100 Bioanalyzer using the Agilent DNA 1000 Kit (Santa Clara, CA). The combined pool of indexed libraries was diluted to $4 \mathrm{nM}$ using $10 \mathrm{mM}$ Tris $\mathrm{pH}$ 8.5. A final $10 \mathrm{pM}$ preparation was created with a 15\% PhiX control spike and analyzed on a MiSeq 600 v3 cartridge. DNA sequences (16S) derived from the bacterial consortia of clinically normal and diseased coral samples as well as reagent and field blanks were treated identically. curated targeted database available there. Classification assignments were then downloaded from the One Codex web site as Microsoft Excel files. Low-abundance, non-informative

372 frequency was less than $0.25 \%$ of the total classification assignments associated with that coral

373 host. Remaining classifications were then combined to obtain master lists of bacterial species

374 found in clinically normal and diseased corals and ranked according to the number of reads

375 classified to each member. Excel pivot tables were used to examine the distribution of

376 identified bacterial species across coral species. 
381 disease state, and inference of biochemical pathways expressed in the consortia. Classifications

382 additionally were filtered to remove those with a prevalence of less than $20 \%$ across samples

383 and features with low variance (less than $10 \%$ based on the interquartile range). Data were

384 transformed using the centered log ratio (CLR) method (79). Alpha diversity was calculated

385 using the Simpson Index expressed as the compliment (ranging between zero and one where

386 larger is more diverse) and tested for significance using Mann-Whitney or Kruskal-Wallis tests

387 as appropriate. Beta diversity was examined using Analysis of Group Similarities (80) of Jenson-

388 Shannon Divergence measures and visualized by NMDS (Nonmetric Multidimensional Scaling).

389 Differences in the bacterial community composition between diseased and clinically normal

390 corals were examined using the edgeR (81) method with an adjusted $p$ value of 0.01 . Finally,

391 gene expression was inferred using the Tax4Fun module (82) of the MicrobiomeAnalyst

392 package. The KEGG KO assignments that were generated were then assigned to major

393 functional groupings and visualized with the MicrobiomeAnalyst Shotgun Data Profiling

394 routines.

Data availability. Raw sequences are available in the National Center for Biotechnology

396 Information (NCBI) Sequence Read Archive (SRA) under project number PRJNA625928,

397 accession numbers SAMN14596532 to SAMN14596550.

\section{ACKNOWLEDGEMENTS}

400

401 Funding for this work was provided by the USGS Ecosystems Mission Area Fisheries Program

402 and by NOAA's Coral Reef Conservation Program Project \# 1133 (C.M.W.). 
404 We thank the National Park Service and the Florida Bay Interagency Science Center, Key Largo

405 FL for providing laboratory and housing facilities and Christopher Kavanagh, Marine Ecologist

406 for coordinating these arrangements and providing logistical support.

407

408 Roles in this research were equally shared by five scientists. W.B.S provided conceptualization, 409 data curation, formal analysis, investigation, methodology, validation, visualization and writing

410 the original draft manuscript. D.D.I. provided data curation, investigation, resources, writing -

411 review and editing. K.M.B. provided funding acquisition, investigation, project administration,

412 resources, supervision and writing - review and editing. C.M.W. provided funding acquisition,

413 investigation, project administration, resources, and writing in review and editing. A.B. provided

414 project administration and resources. K.N. provided resources and writing - review and editing.

415

416 Any use of trade, firm, or product names is for descriptive purposes only and does not imply

417 endorsement by the U.S. Government.

419 Disclaimer: The views and analysis in this manuscript are solely those of the authors and do not 420 necessarily reflect those of NOAA or National Ocean Service. The content of and findings within 421 this document do not reflect NOAA policy. 


\section{REFERENCES}

424 1. Precht WF, Gintert BE, Robbart ML, Fura R, van Woesik R. 2016. Unprecedented

425 Disease-Related Coral Mortality in Southeastern Florida. Sci Rep 6:31374.

$426 \quad 2 . \quad$ FKNMS. 2020. Florida Reef Tract Coral Disease Outbreak: Disease, on Florida Keys

$427 \quad$ National Marine Sanctuary, Office of National Marine Sanctuaries, National Oceanic and

428 Atmospheric Administration, U.S. Department of Commerce. Accessed April 6.

429 3. Neely K. 2018. Surveying the Florida Keys Southern Coral Disease Boundary. Florida

$430 \quad$ DEP, Miami, FL.

4314 Pollock FJ, Morris PJ, Willis BL, Bourne DG. 2011. The Urgent Need for Robust Coral $432 \quad$ Disease Diagnostics. PLoS Path 7:e1002183.

433 5. Walker DI, Ormond RFG. 1982. Coral death from sewage and phosphate pollution at Aqaba, Red Sea. Mar Pollut Bull 13:21-25.

435 6. Neely KL. 2018. Ex-Situ Disease Treatment Trials. Florida DEP, Miami, FL.

$4367 . \quad$ Neely K, Macaulay K, Hower E, Dobler M. 2019. Effectiveness of topical antibiotics in $437 \quad$ treating corals affected by Stony Coral Tissue Loss Disease. bioRxiv 1:870402.

438 8. O'Neil K, Neely K, Patterson J. 2018. Nursery management of disease-raveged pillar coral 439 (Dendrogyra cylindrus) on the Florida Reef Tract. Florida DEP, Miami, FL.

440 9. Voss J, Shilling E, Combs I. 2019. Intervention and fate tracking for corals affected by stony coral tissue loss disease in the northern Florida Reef Tract. Florida DEP, Miami, FL.

442 10. Walker B, Pitts K. 2019. Reef-building-coral Response to Amoxicillin Intervention and Broader-scale Coral Disease Intervention. Florida DEP, Miami, FL. 
444 11. Aeby GS, Ushijima B, Campbell JE, Jones S, Williams GJ, Meyer JL, Häse C, Paul VJ. 2019.

445

446

447

448

449

450

451

452

453

454

455

456

457

458

459

460

461

462

463

464

Pathogenesis of a Tissue Loss Disease Affecting Multiple Species of Corals Along the Florida Reef Tract. Frontiers in Marine Science 6.

12. Ahmad AF, Dwivedi G, O’Gara F, Caparros-Martin J, Ward NC. 2019. The gut microbiome and cardiovascular disease: current knowledge and clinical potential. American Journal of Physiology-Heart and Circulatory Physiology 317:H923-H938.

13. Huttenhower C, Gevers D, Knight R, Abubucker S, Badger JH, Chinwalla AT, Creasy HH, Earl AM, FitzGerald MG, Fulton RS, Giglio MG, Hallsworth-Pepin K, Lobos EA, Madupu R, Magrini V, Martin JC, Mitreva M, Muzny DM, Sodergren EJ, Versalovic J, Wollam AM, Worley KC, Wortman JR, Young SK, Zeng Q, Aagaard KM, Abolude OO, Allen-Vercoe E, Alm EJ, Alvarado L, Andersen GL, Anderson S, Appelbaum E, Arachchi HM, Armitage G, Arze CA, Ayvaz T, Baker CC, Begg L, Belachew T, Bhonagiri V, Bihan M, Blaser MJ, Bloom T, Bonazzi V, Paul Brooks J, Buck GA, Buhay CJ, Busam DA, Campbell JL, et al. 2012. Structure, function and diversity of the healthy human microbiome. Nature 486:207214.

14. Segata N, Izard J, Waldron L, Gevers D, Miropolsky L, Garrett WS, Huttenhower C. 2011. Metagenomic biomarker discovery and explanation. Genome Biol 12:R60.

15. Verster AJ, Borenstein E. 2018. Competitive lottery-based assembly of selected clades in the human gut microbiome. Microbiome 6:186-186.

16. Bass D, Stentiford GD, Wang HC, Koskella B, Tyler CR. 2019. The Pathobiome in Animal and Plant Diseases. Trends Ecol Evol 34:996-1008. 
465 17. Burke C, Thomas T, Lewis M, Steinberg P, Kjelleberg S. 2011. Composition, uniqueness and variability of the epiphytic bacterial community of the green alga Ulva australis. ISME J 5:590-600.

18. Elshahed MS, Najar FZ, Aycock M, Qu C, Roe BA, Krumholz LR. 2005. Metagenomic analysis of the microbial community at Zodletone Spring (Oklahoma): insights into the genome of a member of the novel candidate division OD1. Appl Environ Microbiol 71:7598-602.

472 19. Galbraith H, Iwanowicz D, Spooner D, Iwanowicz L, Keller D, Zelanko P, Adams C. 2018. Exposure to Synthetic Hydraulic Fracturing Waste Influences the Mucosal Bacterial Community Structure of the Brook Trout (Salvelinus fontinalis) Epidermis. AIMS Microbiology 4:413-427.

20. Ainsworth T, Krause L, Bridge T, Torda G, Raina J-B, Zakrzewski M, Gates RD, PadillaO, Leggat W. 2015. The coral core microbiome identifies rare bacterial taxa as ubiquitous endosymbionts. The ISME Journal 9:2261-2274.

480 21. Bernasconi R, Stat M, Koenders A, Paparini A, Bunce M, Huggett MJ. 2019. Community With Host Ontogeny. Front Microbiol 10.

483 22. Huggett MJ, Apprill A. 2019. Coral microbiome database: Integration of sequences reveals high diversity and relatedness of coral-associated microbes. Environ Microbiol 
23. Pollock FJ, McMinds R, Smith S, Bourne DG, Willis BL, Medina M, Thurber RV, Zaneveld JR. 2018. Coral-associated bacteria demonstrate phylosymbiosis and cophylogeny. Nature Communications 9:4921.

24. Sweet MJ, Brown BE, Dunne RP, Singleton I, Bulling M. 2017. Evidence for rapid, tiderelated shifts in the microbiome of the coral Coelastrea aspera. Coral Reefs 36:815-828.

25. Meyer JL, Castellanos-Gell J, Aeby GS, Häse CC, Ushijima B, Paul VJ. 2019. Microbial Community Shifts Associated With the Ongoing Stony Coral Tissue Loss Disease Outbreak on the Florida Reef Tract. Front Microbiol 10.

26. Rosales SM, Clark AS, Huebner LK, Ruzicka RR, Muller EM. 2020. Rhodobacterales and Rhizobiales Are Associated With Stony Coral Tissue Loss Disease and Its Suspected Sources of Transmission. Front Microbiol 11.

27. Siegwald L, Touzet H, Lemoine Y, Hot D, Audebert C, Caboche S. 2017. Assessment of Common and Emerging Bioinformatics Pipelines for Targeted Metagenomics. PLoS One 12:e0169563.

28. Greub G, La Scola B, Raoult D. 2004. Amoebae-resisting bacteria isolated from human nasal swabs by amoebal coculture. Emerg Infect Dis 10:470-7.

29. Thomas V, McDonnell G, Denyer SP, Maillard J-Y. 2010. Free-living amoebae and their intracellular pathogenic microorganisms: risks for water quality. FEMS Microbiol Rev 34:231-259.

30. Strassmann JE, Shu L. 2017. Ancient bacteria-amoeba relationships and pathogenic animal bacteria. PLoS Biol 15:e2002460. 
507 31. Denoncourt AMVEPSJC. 2014. Potential Role of Bacteria Packaging by Protozoa in the Persistence and Transmission of Pathogenic Bacteria. Front Microbiol 5:240.

32. Guimaraes AJ, Gomes KX, Cortines JR, Peralta JM, Peralta RH. 2016. Acanthamoeba spp. as a universal host for pathogenic microorganisms: One bridge from environment to host virulence. Microbiol Res 193:30-38.

512 33. Hilbi H, Weber SS, Ragaz C, Nyfeler Y, Urwyler S. 2007. Environmental predators as models for bacterial pathogenesis. Environ Microbiol 9:563-75.

514 34. Essig A, Heinemann M, Simnacher U, Marre R. 1997. Infection of Acanthamoeba castellanii by Chlamydia pneumoniae. Appl Environ Microbiol 63:1396-9.

35. Jacquier N, Aeby, S., Lienar, J., Greub, G. 2013. Discovery of New Intracellular Pathogens by Amoebal Coculture and Amoebal Enrichment Approaches. Journal of Visualized Experiments 80:51055.

36. Janda WM. 2010. Amoeba-Resistant Bacteria: Their Role in Human Infections. Clin Microbiol Newsl 32:177-184.

521 37. Long JJ, Jahn CE, Sanchez-Hidalgo A, Wheat W, Jackson M, Gonzalez-Juarrero M, Leach oryzae pathovars oryzae and oryzicola. PLoS One 13:e0202941.

524 38. Horn M, Harzenetter MD, Linner T, Schmid EN, Muller KD, Michel R, Wagner M. 2001. Members of the Cytophaga-Flavobacterium-Bacteroides phylum as intracellular bacteria of acanthamoebae: proposal of 'Candidatus Amoebophilus asiaticus'. Environ Microbiol 3:440-9. 
39. Schmitz-Esser S, Tischler P, Arnold R, Montanaro J, Wagner M, Rattei T, Horn M. 2010. The genome of the amoeba symbiont "Candidatus Amoebophilus asiaticus" reveals common mechanisms for host cell interaction among amoeba-associated bacteria. J Bacteriol 192:1045-57.

40. Apprill A, Weber LG, Santoro AE. 2016. Distinguishing between Microbial Habitats Unravels Ecological Complexity in Coral Microbiomes. mSystems 1:e00143-16.

41. Jakobsen $T H$, Hansen MA, Jensen $P \varnothing$, Hansen L, Riber L, Cockburn A, Kolpen $M, R \varnothing n n e$ Hansen C, Ridderberg W, Eickhardt S, Hansen M, Kerpedjiev P, Alhede M, Qvortrup K, Burmølle M, Moser C, Kühl M, Ciofu O, Givskov M, Sørensen SJ, Høiby N, Bjarnsholt T. 2013. Complete Genome Sequence of the Cystic Fibrosis Pathogen Achromobacter xylosoxidans NH44784-1996 Complies with Important Pathogenic Phenotypes. PLoS One 8:e68484.

42. Jeukens J, Freschi L, Vincent AT, Emond-Rheault JG, Kukavica-Ibrulj I, Charette SJ, Levesque RC. 2017. A pan-genomic approach to understand the basis of host adaptation in Achromobacter. Genome Biol Evol 9:1030-1046.

43. Traglia GM, Almuzara M, Merkier AK, Adams C, Galanternik L, Vay C, Centrón D, Ramírez MS. 2012. Achromobacter xylosoxidans: An Emerging Pathogen Carrying Different Elements Involved in Horizontal Genetic Transfer. Curr Microbiol 65:673-678.

44. Morrow KM, Moss AG, Chadwick NE, Liles MR. 2012. Bacterial associates of two Caribbean coral species reveal species-specific distribution and geographic variability. Appl Environ Microbiol 78:6438-6449. 
549 45. Neave MJ, Michell CT, Apprill A, Voolstra CR. 2014. Whole-genome sequences of three symbiotic Endozoicomonas strains. Genome announcements 2:e00802-14.

551 46. Neave MJ, Michell CT, Apprill A, Voolstra CR. 2017. Endozoicomonas genomes reveal functional adaptation and plasticity in bacterial strains symbiotically associated with diverse marine hosts. Sci Rep 7:40579.

47. Schill WB, Iwanowicz D, Adams C. 2017. Endozoicomonas Dominates the Gill and Intestinal Content Microbiomes of Mytilus edulis from Barnegat Bay, New Jersey. J Shellfish Res 36:391-401, 11.

557

558

48. Ding J-Y, Shiu J-H, Chen W-M, Chiang Y-R, Tang S-L. 2016. Genomic Insight into the HostEndosymbiont Relationship of Endozoicomonas montiporae CL-33T with its Coral Host. Front Microbiol 7.

49. Raina JB, Clode PL, Cheong S, Bougoure J, Kilburn MR, Reeder A, Foret S, Stat M, Beltran V, Thomas-Hall P, Tapiolas D, Motti CM, Gong B, Pernice M, Marjo CE, Seymour JR, Willis BL, Bourne DG. 2017. Subcellular tracking reveals the location of dimethylsulfoniopropionate in microalgae and visualises its uptake by marine bacteria. Elife 6.

50. Raina JB, Dinsdale EA, Willis BL, Bourne DG. 2010. Do the organic sulfur compounds DMSP and DMS drive coral microbial associations? Trends Microbiol 18:101-8.

51. Raina JB, Tapiolas D, Motti CA, Foret S, Seemann T, Tebben J, Willis BL, Bourne DG. 2016. Isolation of an antimicrobial compound produced by bacteria associated with reef-building corals. PeerJ 4:e2275. 
52. Raina JB, Tapiolas D, Willis BL, Bourne DG. 2009. Coral-associated bacteria and their role in the biogeochemical cycling of sulfur. Appl Environ Microbiol 75:3492-501.

53. Raina JB, Tapiolas DM, Foret S, Lutz A, Abrego D, Ceh J, Seneca FO, Clode PL, Bourne DG, Willis BL, Motti CA. 2013. DMSP biosynthesis by an animal and its role in coral thermal stress response. Nature 502:677-80.

54. Tandon K, Chiang P-W, Lu C-Y, Yang S-H, Chen Y-F, Wada N, Chen P-Y, Chang H-Y, Chou M-S, Chen W-M, Tang S-L. 2019. Dominant coral bacterium Endozoicomonas acroporae metabolizes DMSP. bioRxiv doi:10.1101/519546:519546.

55. La Rivière M, Roumagnac M, Garrabou J, Bally M. 2013. Transient shifts in bacterial communities associated with the temperate gorgonian Paramuricea clavata in the Northwestern Mediterranean Sea. PLoS One 8:e57385-e57385.

56. Bourne D, lida Y, Uthicke S, Smith-Keune C. 2008. Changes in coral-associated microbial communities during a bleaching event. ISME J 2:350-63.

57. Pantos O, Bongaerts P, Dennis PG, Tyson GW, Hoegh-Guldberg O. 2015. Habitat-specific environmental conditions primarily control the microbiomes of the coral Seriatopora hystrix. The ISME journal 9:1916-1927.

58. Mendoza M, Güiza L, Martinez X, Caraballo X, Rojas J, Aranguren LF, Salazar M. 2013. A novel agent (Endozoicomonas elysicola) responsible for epitheliocystis in cobia Rachycentrum canadum larvae. Dis Aquat Org 106:31-37.

59. Bednarz VN, Grover R, Maguer JF, Fine M, Ferrier-Pages C. 2017. The Assimilation of Diazotroph-Derived Nitrogen by Scleractinian Corals Depends on Their Metabolic Status. mBio 8. 
592

60. Lachnit T, Bosch TCG, Deines P. 2019. Exposure of the Host-Associated Microbiome to Nutrient-Rich Conditions May Lead to Dysbiosis and Disease Development-an Evolutionary Perspective. mBio 10.

61. Staley C, Kaiser T, Gidley ML, Enochs IC, Jones PR, Goodwin KD, Sinigalliano CD, Sadowsky MJ, Chun CL. 2017. Differential Impacts of Land-Based Sources of Pollution on the Microbiota of Southeast Florida Coral Reefs. Appl Environ Microbiol 83:e03378-16.

62. Lapointe BE, Brewton RA, Herren LW, Porter JW, Hu C. 2019. Nitrogen enrichment, altered stoichiometry, and coral reef decline at Looe Key, Florida Keys, USA: a 3-decade study. Mar Biol 166:108.

63. Klinges JG, Rosales SM, McMinds R, Shaver EC, Shantz AA, Peters EC, Eitel M, Wörheide G, Sharp KH, Burkepile DE, Silliman BR, Vega Thurber RL. 2019. Phylogenetic, genomic, and biogeographic characterization of a novel and ubiquitous marine invertebrateassociated Rickettsiales parasite, "Candidatus Aquarickettsia rohweri", gen. nov., sp. nov. The ISME Journal 13:2938-2953.

64. Yang SH, Tandon K, Lu CY, Wada N, Shih CJ, Hsiao SS, Jane WN, Lee TC, Yang CM, Liu CT, Denis V, Wu YT, Wang LT, Huang L, Lee DC, Wu YW, Yamashiro H, Tang SL. 2019. Metagenomic, phylogenetic, and functional characterization of predominant endolithic green sulfur bacteria in the coral Isopora palifera. Microbiome 7:3.

65. Christgen SL, Becker DF. 2017. Role of Proline in Pathogen and Host Interactions. Antioxidants \& Redox Signaling 30:683-709.

66. Passmore IJ, Letertre MPM, Preston MD, Bianconi I, Harrison MA, Nasher F, Kaur H, Hong HA, Baines SD, Cutting SM, Swann JR, Wren BW, Dawson LF. 2018. Para-cresol 
production by Clostridium difficile affects microbial diversity and membrane integrity of Gram-negative bacteria. PLoS Path 14:e1007191-e1007191.

67. Hopper DJ, Bossert ID, Rhodes-Roberts ME. 1991. p-cresol methylhydroxylase from a denitrifying bacterium involved in anaerobic degradation of $\mathrm{p}$-cresol. J Bacteriol 173:1298-1301.

68. Burke C, Steinberg P, Rusch D, Kjelleberg S, Thomas T. 2011. Bacterial community assembly based on functional genes rather than species. Proc Natl Acad Sci U S A 108:14288-93.

69. Muller EM, Sartor C, Alcaraz NI, van Woesik R. 2020. Spatial Epidemiology of the StonyCoral-Tissue-Loss Disease in Florida. Frontiers in Marine Science 7.

70. Banerjee S, Schlaeppi K, van der Heijden MGA. 2018. Keystone taxa as drivers of microbiome structure and functioning. Nature Reviews Microbiology 16:567-576.

71. Hajishengallis G, Darveau RP, Curtis MA. 2012. The keystone-pathogen hypothesis. Nature Reviews Microbiology 10:717-725.

72. Rypien KL, Ward JR, Azam F. 2010. Antagonistic interactions among coral-associated bacteria. Environ Microbiol 12:28-39.

73. Hernandez-Agreda A, Leggat W, Bongaerts P, Herrera C, Ainsworth TD. 2018. Rethinking the Coral Microbiome: Simplicity Exists within a Diverse Microbial Biosphere. mBio 9:e00812-18.

74. Herlemann DPR, Labrenz M, Jürgens K, Bertilsson S, Waniek JJ, Andersson AF. 2011. Transitions in bacterial communities along the $2000 \mathrm{~km}$ salinity gradient of the Baltic Sea. The ISME Journal 5:1571-1579. 
636 75. Klindworth A, Pruesse E, Schweer T, Peplies J, Quast C, Horn M, Glöckner FO. 2012.

76. Klindworth A, Pruesse E, Schweer T, Peplies J, Quast C, Horn M, Glöckner FO. 2013.

77. Minot SK, N.; Greenfield, N.B. 2015. One Codex: A sensitive and accurate data platform for genomic microbial identification. BioRxiv doi:http://dx.doiorg/10.1101/027607.

644 78. Dhariwal A, Chong J, Habib S, King IL, Agellon LB, Xia J. 2017. MicrobiomeAnalyst: a webbased tool for comprehensive statistical, visual and meta-analysis of microbiome data. Nucleic Acids Res 45:W180-W188.

647 79. Gloor GB, Wu JR, Pawlowsky-Glahn V, Egozcue JJ. 2016. It's all relative: analyzing microbiome data as compositions. Ann Epidemiol 26:322-329.

80. Clarke KR. 1993. Non-parametric multivariate analyses of changes in community structure. Aust J Ecol 18:117-143.

651 81. Robinson MD, McCarthy DJ, Smyth GK. 2010. edgeR: a Bioconductor package for differential expression analysis of digital gene expression data. Bioinformatics (Oxford, England) 26:139-140. profiles from metagenomic 16S rRNA data. Bioinformatics 31:2882-2884. 
Table 1. Site number, latitude, longitude, Scientific Name, Abbreviation, Common Name, Status (CN = Clinically Normal, D = Diseased), Depth of Collection (meters), and sample identification of 19 corals collected from Looe Key, Florida.

\begin{tabular}{|c|c|c|c|c|c|c|c|c|}
\hline Site & Latitude & Longitude & Scientific Name & Abbreviation & Common Name & Status & $\begin{array}{c}\text { Depth } \\
\text { (m) }\end{array}$ & Sample ID \\
\hline 1 & N $24^{\circ} 32^{\prime} 40.812^{\prime \prime}$ & W 81ํ 24' 30.96" & Colpophyllia natans & CNAT & boulder brain coral & $\mathrm{D}$ & 6.71 & CNAT_DisBgF \\
\hline 2 & N $24^{\circ} 32^{\prime} 44.988^{\prime \prime}$ & W $81^{\circ} 24^{\prime} 15.84^{\prime \prime}$ & & & & D & 7.01 & CNAT_DisBgBBUnl \\
\hline 2 & N $24^{\circ} 32^{\prime} 44.988^{\prime \prime}$ & W $81^{\circ} 24^{\prime} 15.84^{\prime \prime}$ & & & & $\mathrm{CN}$ & 6.40 & CNATHC-8 \\
\hline 2 & N $24^{\circ} 32^{\prime} 44.988^{\prime \prime}$ & W $81^{\circ} 24^{\prime} 15.84^{\prime \prime}$ & & & & $\mathrm{CN}$ & 5.18 & CNATHC-9 \\
\hline 1 & 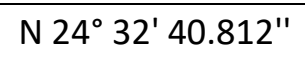 & W 81ํ 24' 30.96" & Dichocoenia stokesii & DSTO & elliptical star coral & $\mathrm{D}$ & 5.49 & DSTO_DisBgJ \\
\hline 1 & N $24^{\circ} 32^{\prime} 40.812^{\prime \prime}$ & W 81ํ2' $30.96^{\prime \prime}$ & & & & D & 5.49 & DSTO_DisBgL \\
\hline 1 & N $24^{\circ} 32^{\prime} 40.812^{\prime \prime}$ & W 81ํㄹ' $24^{\prime} 30.96^{\prime \prime}$ & & & & $\mathrm{CN}$ & 5.49 & DSTOHC-1 \\
\hline 1 & N $24^{\circ} 32^{\prime} 40.812^{\prime \prime}$ & W 81ํ 24' 30.96" & & & & $\mathrm{CN}$ & 5.49 & DSTOHC-3 \\
\hline 1 & 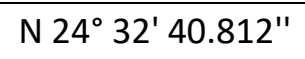 & W 81ํ 24' 30.96" & Diploria labyrinthiformis & DLAB & grooved brain coral & $\mathrm{D}$ & 6.40 & DLAB_DisBgA \\
\hline 2 & N $24^{\circ} 32^{\prime} 44.988^{\prime \prime}$ & W $81^{\circ} 24^{\prime} 15.84^{\prime \prime}$ & & & & D & 5.79 & DLAB_DisBgE \\
\hline 2 & N $24^{\circ} 32^{\prime} 44.988^{\prime \prime}$ & W 81ํ 24' 15.84" & & & & $\mathrm{CN}$ & 7.01 & DLABHC-5 \\
\hline 1 & N 24우 $32^{\prime} 40.812^{\prime \prime}$ & W 81ํ 24' 30.96" & Orbicella annularis & OANN & lobed star coral & D & 7.01 & OANN_DisUNLB \\
\hline 1 & N $24^{\circ} 32^{\prime} 40.812^{\prime \prime}$ & W 81ํ2' 30.96" & & & & D & 7.01 & OANN_DisBgD \\
\hline 2 & N $24^{\circ} 32^{\prime} 44.988^{\prime \prime}$ & W $81^{\circ} 24^{\prime} 15.84^{\prime \prime}$ & & & & $\mathrm{CN}$ & 5.49 & OANNHC-6 \\
\hline 2 & N $24^{\circ} 32^{\prime} 44.988^{\prime \prime}$ & W $81^{\circ} 24^{\prime} 15.84^{\prime \prime}$ & & & & $\mathrm{CN}$ & 5.79 & OANNHC-7 \\
\hline 1 & $\mathrm{~N} 24^{\circ} 32^{\prime} 40.812^{\prime \prime}$ & W 81ํ 24' 30.96" & Pseudodiploria strigosa & PSTR & symmetrical brain coral & $\mathrm{D}$ & 5.49 & PSTR_DisBgH \\
\hline 1 & N $24^{\circ} 32^{\prime} 40.812^{\prime \prime}$ & W 81ํㄹ' $24^{\prime} 30.96^{\prime \prime}$ & & & & D & 5.18 & PSTR_DisBgI \\
\hline 1 & N $24^{\circ} 32^{\prime} 40.812^{\prime \prime}$ & W 81ํ 24' 30.96" & & & & $\mathrm{CN}$ & 5.49 & PSTRHC-2 \\
\hline 1 & N $24^{\circ} 32^{\prime} 40.812^{\prime \prime}$ & W 812 24' 30.96" & & & & $\mathrm{CN}$ & 5.49 & PSTRHC-4 \\
\hline
\end{tabular}


Table 2. Total numbers of classified reads for each library type, reads trimmed $(0.25 \%$ of total bacterial reads classified for each coral host species), and classified reads retained for analysis. CNAT = Colpophyllia natans: DLAB = Diploria labyrinthiformis; DSTO = Dichocoenia stokesii; OANN = Orbicella annularis; and PSTR = Pseudodiploria strigosa.

Host Coral

\begin{tabular}{|l|l|r|r|r|r|r|}
\hline \multicolumn{1}{|c|}{ Library Type } & $\begin{array}{l}\text { Sequence } \\
\text { Reads }\end{array}$ & \multicolumn{1}{|c|}{ CNAT } & DLAB & \multicolumn{1}{c|}{ DSTO } & OANN & \multicolumn{1}{c|}{ PSTR } \\
\hline Diseased & Total & 420,249 & 66,222 & 204,950 & 784,580 & 226,004 \\
\hline & Trimmed & $<1,051$ & $<166$ & $<512$ & $<1,961$ & $<565$ \\
\hline & Retained & 419,198 & 66,056 & 204,438 & 782,619 & 225,438 \\
\hline & & & & & & \\
\hline Clinically Normal & Total & 462,966 & 85,138 & 77,018 & 38,349 & 121,738 \\
\hline & Trimmed & $<1,157$ & $<213$ & $<193$ & $<96$ & $<304$ \\
\hline & Retained & 461,808 & 84,925 & 76,825 & 38,253 & 121434 \\
\hline
\end{tabular}


Table 3. Distribution of classified bacterial sequences across clinically normal host coral species. CNAT = Colpophyllia natans: DLAB = Diploria labyrinthiformis; DSTO = Dichocoenia stokesii; OANN = Orbicella annularis; and PSTR = Pseudodiploria strigosa.

\begin{tabular}{|c|c|c|c|c|c|c|}
\hline Microbe & CNAT & DLAB & DSTO & OANN & PSTR & $\begin{array}{l}\text { Species } \\
\text { Affected }\end{array}$ \\
\hline Achromobacter xylosoxidans & $x$ & $\mathbf{x}$ & $\mathbf{x}$ & $\mathbf{x}$ & $\mathbf{x}$ & 5 \\
\hline Achromobacter denitrificans & $\mathbf{x}$ & $\mathbf{x}$ & & $x$ & $x$ & 4 \\
\hline "Candidatus Amoebophilus asiaticus" & $x$ & $x$ & & $x$ & $x$ & 4 \\
\hline Fulvivirga imtechensis & $\mathbf{x}$ & $x$ & & $x$ & $\mathbf{x}$ & 4 \\
\hline Fulvivirga kasyanovii & $x$ & $x$ & & $x$ & $x$ & 4 \\
\hline Fabibacter misakiensis & & $x$ & & $x$ & $x$ & 3 \\
\hline Fulvivirga lutimaris & $x$ & $x$ & & $x$ & & 3 \\
\hline Nitrincola lacisaponensis & $x$ & & $x$ & & $x$ & 3 \\
\hline Rhodospirillum rubrum & $x$ & $x$ & & $x$ & & 3 \\
\hline Sinorhizobium fredii & $x$ & & $x$ & & $x$ & 3 \\
\hline 171 More-found on one or two hosts & & & & & & \\
\hline
\end{tabular}


Table 4. Distribution of classified bacterial sequences across diseased coral hosts. CNAT = Colpophyllia natans: DLAB = Diploria labyrinthiformis; DSTO = Dichocoenia stokesii; OANN = Orbicella annularis; and PSTR = Pseudodiploria strigosa.

\begin{tabular}{|c|c|c|c|c|c|c|}
\hline Microbe & CNAT & DLAB & DSTO & OANN & PSTR & $\begin{array}{c}\text { Species } \\
\text { Affected }\end{array}$ \\
\hline Algicola bacteriolytica & $x$ & $x$ & $x$ & $x$ & $x$ & 5 \\
\hline Arcobacter bivalviorum & $x$ & $x$ & $\mathbf{x}$ & $x$ & $x$ & 5 \\
\hline Clostridioides difficile & $x$ & $x$ & $x$ & $x$ & $x$ & 5 \\
\hline Arcobacter sp. UDC415 & & $x$ & $x$ & $\mathbf{x}$ & $x$ & 4 \\
\hline "Candidatus Amoebophilus asiaticus" & $x$ & $x$ & $x$ & $x$ & & 4 \\
\hline Pseudofulvibacter geojedonensis & & $x$ & $x$ & & $x$ & 3 \\
\hline Romboutsia lituseburensis & $x$ & & $x$ & & $x$ & 3 \\
\hline Shimia aquaeponti & $x$ & & $x$ & $x$ & & 3 \\
\hline Vibrio sp. r24 & $x$ & & $x$ & & $x$ & 3 \\
\hline 95 More- found on one or two hosts & & & & & & \\
\hline
\end{tabular}


Table 5. Bacterial species enriched in diseased coral hosts as determined by edgeR contrast analysis. Designations are predicated at a false discovery rate (FDR) $<0.01$. Shown are the logarithm of 2 -fold change $(\log 2 \mathrm{FC})$, the logarithm of counts per million reads $\left(\log _{2} \mathrm{CPM}\right)$, the Benjamini-Hochberg (B-H) adjusted $\mathrm{P}$ value (Pvalue), and the FDR. The table is sorted from highest to lowest abundance ( $\left.\log _{2} \mathrm{CPM}\right)$.

\begin{tabular}{|c|c|c|c|c|}
\hline Bacterial Species & $\log 2 \mathrm{FC}$ & $\log _{2} \mathrm{CPM}$ & Pvalue & FDR \\
\hline Clostridioides difficile & 5.832 & 16.425 & $3.160 \mathrm{E}-06$ & $9.071 \mathrm{E}-06$ \\
\hline Arcobacter bivalviorum & 11.320 & 16.378 & $1.253 \mathrm{E}-11$ & $2.042 \mathrm{E}-09$ \\
\hline Tepidibacter mesophilus & 8.471 & 13.556 & $1.669 \mathrm{E}-06$ & $5.440 \mathrm{E}-06$ \\
\hline Algicola bacteriolytica & 4.113 & 13.416 & $1.801 \mathrm{E}-03$ & $2.718 \mathrm{E}-03$ \\
\hline Shimia aquaeponti & 8.262 & 13.341 & $1.943 \mathrm{E}-07$ & $1.131 \mathrm{E}-06$ \\
\hline Vibrio sp. r24 & 8.190 & 13.263 & $1.752 \mathrm{E}-08$ & $2.561 \mathrm{E}-07$ \\
\hline Marinilabilia nitratireducens & 7.999 & 13.082 & $3.786 \mathrm{E}-07$ & $1.870 \mathrm{E}-06$ \\
\hline Burkholderia gladioli & 7.912 & 12.996 & $4.535 \mathrm{E}-07$ & 2.174E-06 \\
\hline Pseudofulvibacter geojedonensis & 7.795 & 12.885 & $2.781 \mathrm{E}-06$ & $8.243 E-06$ \\
\hline Marinifilum fragile & 7.756 & 12.845 & $1.299 \mathrm{E}-06$ & 4.504E-06 \\
\hline Staphylococcus epidermidis & 3.957 & 12.802 & 4.630E-03 & $6.799 \mathrm{E}-03$ \\
\hline Vibrio nigripulchritudo & 7.559 & 12.638 & $3.033 \mathrm{E}-08$ & $3.166 \mathrm{E}-07$ \\
\hline Pseudahrensia aquimaris & 7.477 & 12.577 & $1.191 \mathrm{E}-05$ & $2.520 \mathrm{E}-05$ \\
\hline Tenacibaculum litopenaei & 7.367 & 12.464 & $2.712 \mathrm{E}-06$ & $8.185 E-06$ \\
\hline Abyssivirga alkaniphila & 4.250 & 12.215 & $2.063 \mathrm{E}-03$ & $3.084 \mathrm{E}-03$ \\
\hline Amphritea japonica & 7.080 & 12.169 & $5.726 \mathrm{E}-08$ & 5.490E-07 \\
\hline Romboutsia lituseburensis & 7.009 & 12.094 & $1.885 \mathrm{E}-08$ & $2.561 \mathrm{E}-07$ \\
\hline Vibrio alginolyticus & 6.990 & 12.070 & $2.569 \mathrm{E}-09$ & $6.978 \mathrm{E}-08$ \\
\hline Carboxylicivirga taeanensis & 6.870 & 11.979 & $6.971 \mathrm{E}-06$ & $1.623 \mathrm{E}-05$ \\
\hline Meridianimaribacter flavus & 6.601 & 11.713 & $1.571 \mathrm{E}-06$ & $5.226 \mathrm{E}-06$ \\
\hline Rhizobium sp. Trp 3 & 6.397 & 11.519 & 4.939E-06 & $1.258 \mathrm{E}-05$ \\
\hline Vibrio harveyi & 6.314 & 11.409 & 2.097E-09 & $6.836 \mathrm{E}-08$ \\
\hline Arcobacter molluscorum & 6.236 & 11.364 & 4.615E-06 & $1.194 \mathrm{E}-05$ \\
\hline Mesorhizobium sp. & 6.210 & 11.341 & $9.035 \mathrm{E}-06$ & $2.045 \mathrm{E}-05$ \\
\hline
\end{tabular}




\begin{tabular}{|c|c|c|c|c|}
\hline Yersinia enterocolitica & 6.165 & 11.286 & $5.160 \mathrm{E}-07$ & $2.336 \mathrm{E}-06$ \\
\hline Shimia isoporae & 6.062 & 11.193 & $1.990 \mathrm{E}-06$ & $6.360 \mathrm{E}-06$ \\
\hline Natronoflexus pectinivorans & 5.979 & 11.117 & $6.027 \mathrm{E}-06$ & $1.489 \mathrm{E}-05$ \\
\hline Vibrio parahaemolyticus & 5.961 & 11.072 & $4.088 \mathrm{E}-09$ & $9.519 \mathrm{E}-08$ \\
\hline Fusibacter paucivorans & 5.876 & 11.019 & 4.533E-06 & $1.192 \mathrm{E}-05$ \\
\hline Eubacterium tenue & 5.801 & 10.948 & $3.972 \mathrm{E}-06$ & $1.061 \mathrm{E}-05$ \\
\hline Aestuariibacter halophilus & 5.789 & 10.941 & $1.074 \mathrm{E}-05$ & 2.399E-05 \\
\hline Lentibacter algarum & 5.586 & 10.749 & $8.574 \mathrm{E}-06$ & $1.968 \mathrm{E}-05$ \\
\hline Clostridium thermosuccinogenes & 5.576 & 10.732 & $2.431 \mathrm{E}-06$ & $7.621 \mathrm{E}-06$ \\
\hline Pseudoalteromonas haloplanktis & 5.541 & 10.685 & 7.903E-08 & $6.134 \mathrm{E}-07$ \\
\hline Mesorhizobium loti & 5.431 & 10.593 & $8.378 \mathrm{E}-07$ & $3.339 \mathrm{E}-06$ \\
\hline Oceanirhabdus sediminicola & 5.420 & 10.593 & $1.106 \mathrm{E}-05$ & $2.403 \mathrm{E}-05$ \\
\hline Thalassolituus oleivorans & 5.405 & 10.553 & $3.108 \mathrm{E}-08$ & $3.166 \mathrm{E}-07$ \\
\hline Ketogulonicigenium vulgare & 5.362 & 10.521 & $1.754 \mathrm{E}-07$ & $1.077 \mathrm{E}-06$ \\
\hline Tissierella creatinini & 5.257 & 10.443 & $1.833 \mathrm{E}-05$ & $3.727 \mathrm{E}-05$ \\
\hline Vibrio vulnificus & 5.169 & 10.334 & $2.574 \mathrm{E}-08$ & 2.997E-07 \\
\hline Alkaliphilus peptidifermentans & 5.054 & 10.241 & $5.114 \mathrm{E}-07$ & $2.336 \mathrm{E}-06$ \\
\hline Roseovarius aestuarii & 4.988 & 10.185 & $9.409 \mathrm{E}-07$ & $3.573 E-06$ \\
\hline Bythopirellula goksoyri & 4.962 & 10.180 & $3.012 \mathrm{E}-05$ & $5.644 \mathrm{E}-05$ \\
\hline Tissierella praeacuta & 4.791 & 10.023 & $2.896 \mathrm{E}-05$ & $5.489 \mathrm{E}-05$ \\
\hline Myroides indicus & 4.649 & 9.901 & 4.199E-05 & $7.690 \mathrm{E}-05$ \\
\hline Tindallia magadiensis & 4.619 & 9.870 & $1.852 \mathrm{E}-05$ & 3.727E-05 \\
\hline Marinifilum albidiflavum & 4.582 & 9.837 & $1.589 \mathrm{E}-05$ & $3.278 \mathrm{E}-05$ \\
\hline Epibacterium multivorans & 4.538 & 9.796 & $1.096 \mathrm{E}-05$ & 2.403E-05 \\
\hline Rhizobium tropici & 4.513 & 9.774 & $1.125 \mathrm{E}-05$ & $2.412 \mathrm{E}-05$ \\
\hline Cohaesibacter gelatinilyticus & 4.399 & 9.684 & $4.486 \mathrm{E}-05$ & 8.124E-05 \\
\hline Amphritea ceti & 4.285 & 9.572 & $6.391 \mathrm{E}-06$ & $1.551 \mathrm{E}-05$ \\
\hline Hoeflea phototrophica & 4.195 & 9.521 & $2.868 \mathrm{E}-04$ & $4.583 E-04$ \\
\hline Cohaesibacter haloalkalitolerans & 4.186 & 9.505 & $8.503 E-05$ & $1.444 \mathrm{E}-04$ \\
\hline
\end{tabular}


bioRxiv preprint doi: https://doi.org/10.1101/2020.05.27.120469; this version posted June 18, 2020. The copyright holder for this preprint (which was not certified by peer review) is the author/funder. This article is a US Government work. It is not subject to copyright under 17 USC 105 and is also made available for use under a CCO license.

Pseudoteredinibacter isoporae

Vibrio cholerae

Clostridium scindens

Sunxiuqinia elliptica

Streptomyces lazureus

Kordiimonas gwangyangensis
4.144

4.140

4.040

3.992

3.931

3.665
$9.473 \quad 1.133 \mathrm{E}-04$

$9.464 \quad 5.581 \mathrm{E}-05$

$9.388 \quad 2.032 \mathrm{E}-04$

9.352

$3.222 \mathrm{E}-04$

$9.297 \quad 1.627 \mathrm{E}-04$

9.089
1.903E-04

9.996E-05

3.280E-04

5.098E-04

2.652E-04

5.533E-04 
Table 6. Bacterial species enriched in clinically normal coral hosts as determined by edgeR contrast analysis. Designations are predicated at a false discovery rate $(F D R)<$ 0.01 . Shown are the logarithm of 2 -fold change (log2FC), the logarithm of counts per million reads ( $\left.\log _{2} \mathrm{CPM}\right)$, the Benjamini-Hochberg $(\mathrm{B}-\mathrm{H})$ adjusted $\mathrm{P}$ value (Pvalue), and the FDR. The table is sorted from highest to lowest abundance ( $\left.\log _{2} \mathrm{CPM}\right)$.

\begin{tabular}{|c|c|c|c|c|}
\hline Bacterial Species & $\log 2 \mathrm{FC}$ & $\log _{2} \mathrm{CPM}$ & Pvalue & FDR \\
\hline Heliothrix oregonensis & -10.362 & 15.430 & $6.492 \mathrm{E}-08$ & $5.569 E-07$ \\
\hline Aureivirga marina & -10.051 & 15.121 & $2.288 \mathrm{E}-07$ & $1.243 \mathrm{E}-06$ \\
\hline Blastocatella fastidiosa & -3.996 & 14.774 & $5.076 \mathrm{E}-03$ & $7.388 \mathrm{E}-03$ \\
\hline Chloroflexus aurantiacus & -3.283 & 13.728 & 4.550E-03 & $6.742 \mathrm{E}-03$ \\
\hline Mycoplasma mycoides & -4.034 & 13.702 & $1.188 \mathrm{E}-03$ & $1.809 \mathrm{E}-03$ \\
\hline Spirosoma navajo & -8.304 & 13.383 & $2.275 \mathrm{E}-08$ & $2.852 \mathrm{E}-07$ \\
\hline Muricauda lutaonensis & -7.559 & 12.652 & $9.644 \mathrm{E}-07$ & $3.573 E-06$ \\
\hline Iamia majanohamensis & -7.537 & 12.632 & $1.785 \mathrm{E}-07$ & 1.077E-06 \\
\hline Streptococcus sanguinis & -7.125 & 12.227 & $9.605 \mathrm{E}-07$ & $3.573 E-06$ \\
\hline Candidatus Solibacter usitatus & -6.976 & 12.083 & $3.459 E-07$ & $1.762 \mathrm{E}-06$ \\
\hline Spirochaeta halophila & -6.873 & 11.983 & $2.153 \mathrm{E}-07$ & $1.210 \mathrm{E}-06$ \\
\hline Bacillus licheniformis & -6.848 & 11.958 & $1.708 \mathrm{E}-07$ & 1.077E-06 \\
\hline Klebsiella pneumoniae & -6.813 & 11.925 & 8.615E-09 & $1.560 \mathrm{E}-07$ \\
\hline Vibrio sp. $\mathrm{Cl} \mathrm{G9}$ & -6.470 & 11.595 & $3.172 \mathrm{E}-06$ & $9.071 \mathrm{E}-06$ \\
\hline Marinoscillum furvescens & -6.464 & 11.591 & $7.350 \mathrm{E}-07$ & $3.153 E-06$ \\
\hline Dictyoglomus turgidum & -6.451 & 11.575 & $6.448 \mathrm{E}-08$ & $5.569 \mathrm{E}-07$ \\
\hline Candidatus Phytoplasma fraxini & -6.442 & 11.567 & 5.657E-09 & 1.153E-07 \\
\hline Fulvivirga kasyanovii & -6.435 & 11.563 & $1.025 \mathrm{E}-07$ & $7.596 \mathrm{E}-07$ \\
\hline Candidatus Liberibacter asiaticus & -6.419 & 11.545 & $1.214 \mathrm{E}-08$ & $1.979 \mathrm{E}-07$ \\
\hline Aeromonas caviae & -6.406 & 11.533 & $1.586 \mathrm{E}-07$ & $1.077 \mathrm{E}-06$ \\
\hline Aciditerrimonas ferrireducens & -6.282 & 11.421 & $2.604 \mathrm{E}-06$ & 8.009E-06 \\
\hline Arthrobacter davidanieli & -6.194 & 11.331 & $6.928 \mathrm{E}-07$ & $3.052 \mathrm{E}-06$ \\
\hline Labilibacter aurantiacus & -5.993 & 11.144 & 6.794E-06 & $1.605 \mathrm{E}-05$ \\
\hline Tamlana agarivorans & -5.991 & 11.140 & $1.557 \mathrm{E}-06$ & $5.226 \mathrm{E}-06$ \\
\hline
\end{tabular}




\begin{tabular}{|c|c|c|c|c|}
\hline Oenococcus oeni & -5.984 & 11.133 & 7.049E-08 & $5.745 \mathrm{E}-07$ \\
\hline Algisphaera agarilytica & -5.923 & 11.079 & 8.398E-07 & 3.339E-06 \\
\hline Eionea nigra & -5.829 & 10.990 & $6.472 \mathrm{E}-06$ & $1.551 \mathrm{E}-05$ \\
\hline Ilumatobacter fluminis & -5.552 & 10.737 & $3.232 \mathrm{E}-06$ & $9.082 \mathrm{E}-06$ \\
\hline Sinorhizobium medicae & -5.397 & 10.586 & $1.837 \mathrm{E}-10$ & 1.497E-08 \\
\hline Pseudomonas marincola & -5.360 & 10.558 & $9.923 \mathrm{E}-07$ & 3.594E-06 \\
\hline Gloeobacter violaceus & -5.269 & 10.472 & $2.584 \mathrm{E}-07$ & 1.359E-06 \\
\hline Pseudomonas putida & -5.245 & 10.452 & $1.275 \mathrm{E}-06$ & 4.504E-06 \\
\hline Moraxella catarrhalis & -5.109 & 10.326 & $7.350 \mathrm{E}-10$ & 3.993E-08 \\
\hline Bartonella bacilliformis & -5.068 & 10.290 & $1.052 \mathrm{E}-09$ & $4.288 \mathrm{E}-08$ \\
\hline Bdellovibrio bacteriovorus & -4.794 & 10.052 & $1.997 \mathrm{E}-05$ & 3.970E-05 \\
\hline Pectobacterium atrosepticum & -4.780 & 10.040 & $1.274 \mathrm{E}-05$ & $2.662 \mathrm{E}-05$ \\
\hline Sulfobacillus thermosulfidooxidans & -4.777 & 10.036 & $8.062 \mathrm{E}-07$ & 3.339E-06 \\
\hline Serratia liquefaciens & -4.732 & 9.998 & $3.617 E-06$ & 9.955E-06 \\
\hline Haloferula chungangensis & -4.553 & 9.845 & 2.867E-05 & $5.489 \mathrm{E}-05$ \\
\hline Roseivirga marina & -4.509 & 9.807 & 5.499E-06 & $1.379 \mathrm{E}-05$ \\
\hline Thioprofundum lithotrophicum & -4.437 & 9.743 & 1.379E-07 & $9.776 \mathrm{E}-07$ \\
\hline Aridibacter kavangonensis & -4.347 & 9.671 & $3.665 \mathrm{E}-06$ & $9.955 E-06$ \\
\hline Coxiella burnetii & -4.084 & 9.456 & 4.122E-05 & $7.635 \mathrm{E}-05$ \\
\hline Gimesia maris & -4.078 & 9.452 & $2.079 \mathrm{E}-05$ & 4.084E-05 \\
\hline Thalassotalea agarivorans & -4.006 & 9.393 & $6.572 E-05$ & $1.152 E-04$ \\
\hline Roseivirga spongicola & -3.970 & 9.365 & $2.736 \mathrm{E}-05$ & $5.309 \mathrm{E}-05$ \\
\hline Lawsonella clevelandensis & -3.882 & 9.296 & 8.244E-05 & $1.415 \mathrm{E}-04$ \\
\hline Spiribacter curvatus & -3.762 & 9.203 & 7.087E-05 & $1.229 \mathrm{E}-04$ \\
\hline Ruegeria intermedia & -3.647 & 9.113 & 5.797E-05 & 1.027E-04 \\
\hline Lewinella cohaerens & -3.603 & 9.083 & $1.482 \mathrm{E}-04$ & $2.441 E-04$ \\
\hline Ekhidna lutea & -3.299 & 8.862 & $1.211 \mathrm{E}-04$ & $2.015 \mathrm{E}-04$ \\
\hline Gluconobacter oxydans & -3.248 & 8.824 & $5.105 E-04$ & 7.849E-04 \\
\hline Portibacter lacus & -3.118 & 8.736 & $3.608 \mathrm{E}-04$ & 5.601E-04 \\
\hline
\end{tabular}


Table 7. Bacterial species present in both diseased and clinically normal coral host samples. Designations are predicated at a false discovery rate (FDR) $<0.01$. Shown are the logarithm of 2 -fold change $(\log 2 \mathrm{FC})$, the logarithm of counts per million reads ( $\left.\log _{2} \mathrm{CPM}\right)$, the Benjamini-Hochberg $(\mathrm{B}-\mathrm{H})$ adjusted $\mathrm{P}$ value (Pvalue), and the false discovery rate (FDR). The table is sorted from highest to lowest abundance $\left(\log _{2} C P M\right)$.

\begin{tabular}{|c|c|c|c|c|}
\hline Bacterial Species & $\log 2 \mathrm{FC}$ & $\log C P M$ & Pvalue & FDR \\
\hline Prosthecochloris vibrioformis & -0.204 & 16.350 & $8.764 \mathrm{E}-01$ & 8.929E-01 \\
\hline "Candidatus Amoebophilus asiaticus" & -2.296 & 16.193 & 7.091E-02 & $9.713 \mathrm{E}-02$ \\
\hline Arcobacter sp. UDC415 & 2.027 & 15.337 & 1.499E-01 & $1.894 \mathrm{E}-01$ \\
\hline Arcobacter nitrofigilis & 1.707 & 14.929 & $3.458 \mathrm{E}-01$ & 3.969E-01 \\
\hline Rhodospirillum rubrum & -2.420 & 14.804 & 7.877E-02 & $1.061 \mathrm{E}-01$ \\
\hline Achromobacter xylosoxidans & -1.509 & 14.608 & $1.575 \mathrm{E}-01$ & $1.975 \mathrm{E}-01$ \\
\hline Aquimarina muelleri & 1.041 & 13.905 & $5.184 \mathrm{E}-01$ & $5.788 \mathrm{E}-01$ \\
\hline Roseivirga seohaensis & -0.235 & 13.847 & 8.593E-01 & 8.865E-01 \\
\hline Halodesulfovibrio spirochaetisodalis & 2.843 & 13.371 & $6.094 \mathrm{E}-02$ & 8.563E-02 \\
\hline Tepidicaulis marinus & 3.848 & 13.261 & $7.222 \mathrm{E}-03$ & $1.042 \mathrm{E}-02$ \\
\hline Candidatus Pelagibacter ubique & -1.488 & 13.253 & $2.255 \mathrm{E}-01$ & $2.723 \mathrm{E}-01$ \\
\hline Fulvivirga imtechensis & -1.281 & 12.590 & $2.811 \mathrm{E}-01$ & 3.344E-01 \\
\hline Halodesulfovibrio oceani & -0.620 & 12.524 & $6.381 \mathrm{E}-01$ & $6.843 \mathrm{E}-01$ \\
\hline Halodesulfovibrio marinisediminis & -2.349 & 12.495 & $8.180 \mathrm{E}-02$ & $1.093 \mathrm{E}-01$ \\
\hline Achromobacter denitrificans & -1.600 & 12.418 & $1.092 \mathrm{E}-01$ & $1.435 \mathrm{E}-01$ \\
\hline Pectobacterium carotovorum & 0.404 & 12.300 & 7.613E-01 & 7.955E-01 \\
\hline Pirellula sp. & 0.468 & 12.241 & $6.948 \mathrm{E}-01$ & 7.402E-01 \\
\hline Pseudovibrio denitrificans & 2.105 & 12.177 & $1.152 \mathrm{E}-01$ & $1.467 \mathrm{E}-01$ \\
\hline Aquisalinus flavus & 1.354 & 12.177 & $3.023 E-01$ & $3.530 \mathrm{E}-01$ \\
\hline Alteromonas macleodii & -0.096 & 12.151 & $9.073 \mathrm{E}-01$ & $9.073 \mathrm{E}-01$ \\
\hline Wukongibacter baidiensis & -0.132 & 12.088 & $9.050 \mathrm{E}-01$ & 9.073E-01 \\
\hline Kiloniella spongiae & 1.650 & 12.028 & 2.665E-01 & 3.194E-01 \\
\hline Clostridium botulinum & -0.555 & 11.918 & $5.812 \mathrm{E}-01$ & $6.428 \mathrm{E}-01$ \\
\hline Nitrincola lacisaponensis & -1.234 & 11.911 & $1.692 \mathrm{E}-01$ & $2.074 \mathrm{E}-01$ \\
\hline
\end{tabular}




\begin{tabular}{|c|c|c|c|c|}
\hline Rubritalea tangerina & 1.993 & 11.909 & $8.334 \mathrm{E}-02$ & $1.104 \mathrm{E}-01$ \\
\hline Azospirillum brasilense & -2.278 & 11.752 & $4.922 \mathrm{E}-02$ & 7.013E-02 \\
\hline Thalassobius mediterraneus & 1.691 & 11.707 & $1.601 \mathrm{E}-01$ & $1.987 \mathrm{E}-01$ \\
\hline Achromobacter marplatensis & -1.708 & 11.609 & 7.195E-02 & $9.774 \mathrm{E}-02$ \\
\hline Pseudoalteromonas tetraodonis & 1.576 & 11.576 & $4.948 \mathrm{E}-02$ & 7.013E-02 \\
\hline Microcystis aeruginosa & -0.183 & 11.557 & $8.340 \mathrm{E}-01$ & 8.659E-01 \\
\hline Fulvivirga lutimaris & -1.187 & 11.513 & $3.032 \mathrm{E}-01$ & $3.530 \mathrm{E}-01$ \\
\hline Sinorhizobium fredii & -0.496 & 11.482 & $5.837 \mathrm{E}-01$ & $6.428 \mathrm{E}-01$ \\
\hline Fabibacter misakiensis & -0.160 & 11.468 & $8.690 \mathrm{E}-01$ & $8.908 \mathrm{E}-01$ \\
\hline Riemerella anatipestifer & 0.478 & 11.461 & 7.176E-01 & 7.595E-01 \\
\hline Prosthecochloris indica & 0.906 & 11.447 & 4.719E-01 & $5.305 \mathrm{E}-01$ \\
\hline Mesoplasma florum & -1.018 & 11.403 & $3.309 \mathrm{E}-01$ & $3.826 \mathrm{E}-01$ \\
\hline Amphiplicatus metriothermophilus & 0.592 & 11.367 & $6.276 \mathrm{E}-01$ & $6.774 \mathrm{E}-01$ \\
\hline Halodesulfovibrio aestuarii & 1.369 & 11.365 & $3.006 \mathrm{E}-01$ & 3.530E-01 \\
\hline Hoeflea halophila & -0.880 & 11.325 & $4.411 \mathrm{E}-01$ & 4.993E-01 \\
\hline Aeromonas salmonicida & 0.162 & 11.313 & $8.865 \mathrm{E}-01$ & $8.975 \mathrm{E}-01$ \\
\hline Anaplasma platys & -1.428 & 11.310 & $1.609 \mathrm{E}-01$ & $1.987 \mathrm{E}-01$ \\
\hline Phyllobacterium leguminum & 2.050 & 11.304 & $1.137 \mathrm{E}-01$ & 1.467E-01 \\
\hline Thermanaerovibrio acidaminovorans & -2.019 & 11.214 & $6.707 E-02$ & $9.264 \mathrm{E}-02$ \\
\hline Pelagibius litoralis & -1.730 & 11.175 & $1.149 \mathrm{E}-01$ & 1.467E-01 \\
\hline Mycoplasma gallisepticum & -1.600 & 11.071 & $6.322 \mathrm{E}-02$ & $8.808 \mathrm{E}-02$ \\
\hline Woeseia oceani & 0.591 & 11.061 & $6.016 \mathrm{E}-01$ & $6.537 \mathrm{E}-01$ \\
\hline Bartonella henselae & -0.495 & 10.981 & $5.985 \mathrm{E}-01$ & $6.537 \mathrm{E}-01$ \\
\hline Lentisphaera profundi & 1.572 & 10.951 & $1.150 \mathrm{E}-01$ & 1.467E-01 \\
\hline Natranaerovirga hydrolytica & 1.088 & 10.929 & $3.718 \mathrm{E}-01$ & $4.238 \mathrm{E}-01$ \\
\hline Acinetobacter radioresistens & -0.387 & 10.845 & $7.250 \mathrm{E}-01$ & 7.624E-01 \\
\hline Thermosynechococcus elongatus & 1.385 & 10.806 & $1.772 \mathrm{E}-01$ & 2.155E-01 \\
\hline
\end{tabular}


bioRxiv preprint doi: https://doi.org/10.1101/2020.05.27.120469; this version posted June 18, 2020. The copyright holder for this preprint (which was not certified by peer review) is the author/funder. This article is a US Government work. It is not subject to copyright under 17 USC 105 and is also made available for use under a CCO license.

FIG 1. Representative samples of five coral species affected by Stony Coral Tissue Loss Disease (SCTLD) at Looe Key, FL in August 2018.

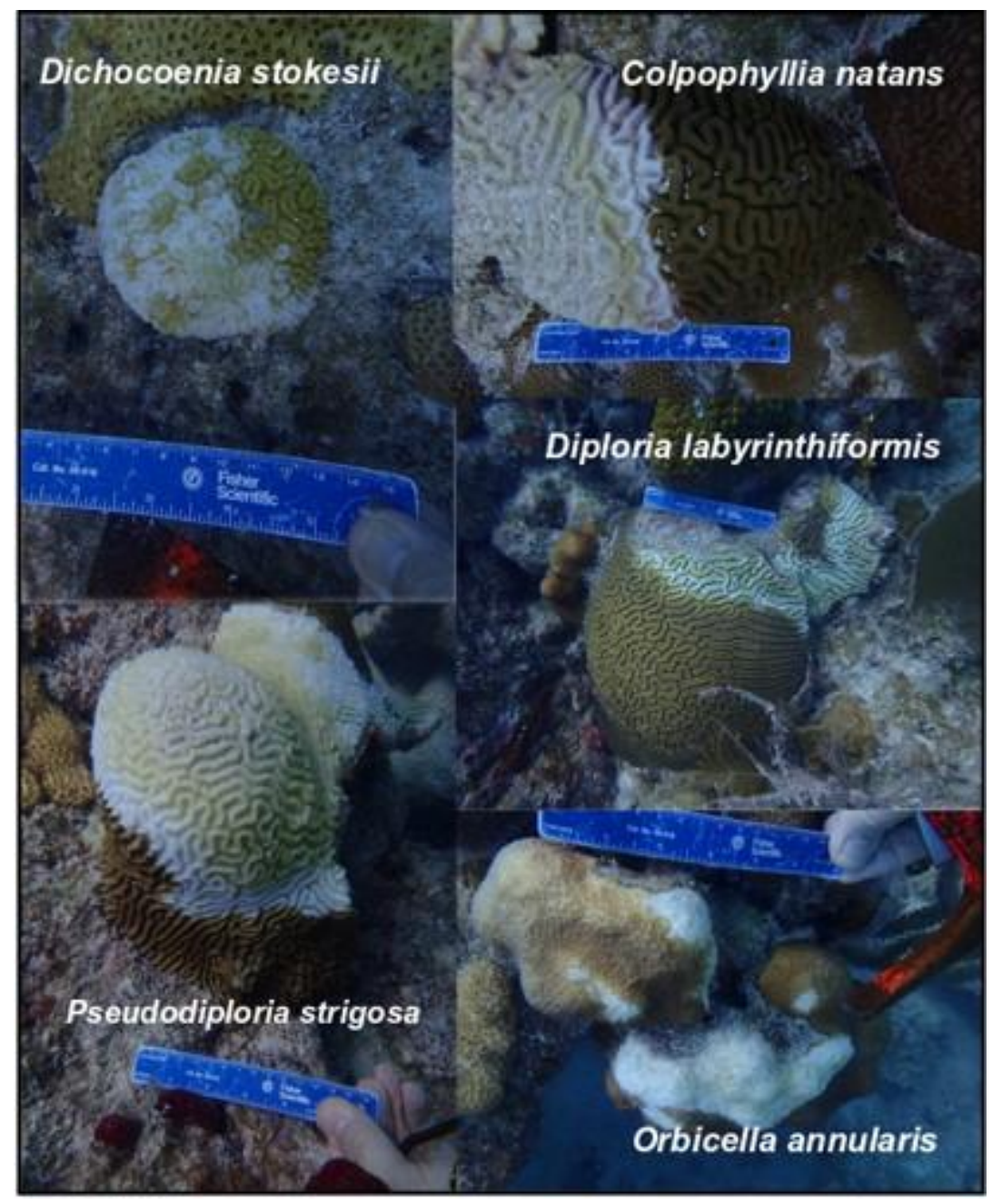


bioRxiv preprint doi: https://doi.org/10.1101/2020.05.27.120469; this version posted June 18, 2020. The copyright holder for this preprint (which was not certified by peer review) is the author/funder. This article is a US Government work. It is not subject to copyright under 17 USC 105 and is also made available for use under a CCO license.

FIG 2. Alpha diversity as measured by the Simpson index was generally similar among the microbiomes of all five coral hosts species regardless of health status.

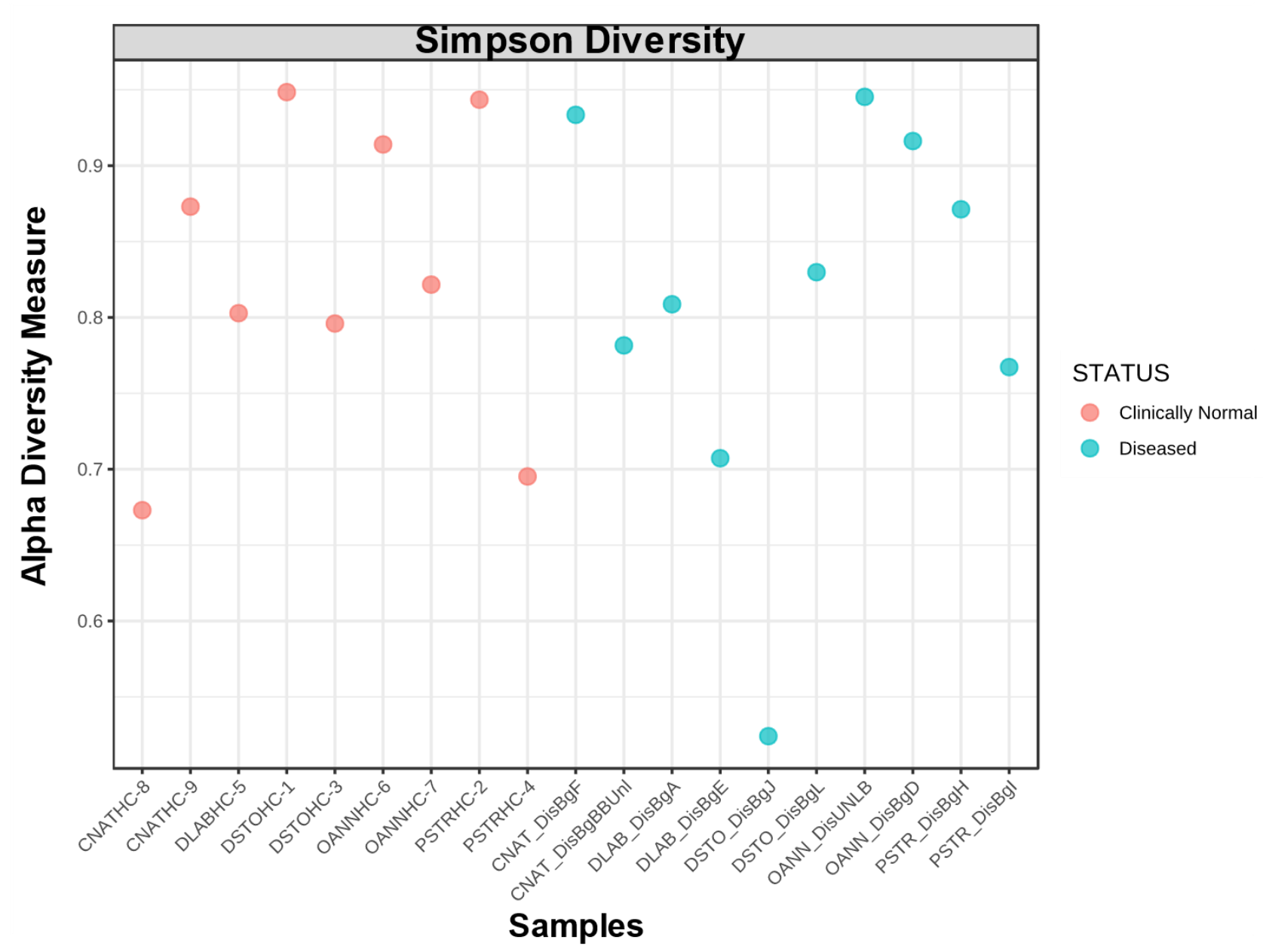


bioRxiv preprint doi: https://doi.org/10.1101/2020.05.27.120469; this version posted June 18, 2020. The copyright holder for this preprint (which was not certified by peer review) is the author/funder. This article is a US Government work. It is not subject to copyright under 17 USC 105 and is also made available for use under a CCO license.

FIG 3. Nonmetric multidimensional scaling visualization of Jenson-Shannon Divergence measures using ANOSIM demonstrated that the microbiome taxa of five stony coral species affected by SCTLD are distinct between clinically normal and diseased colonies.

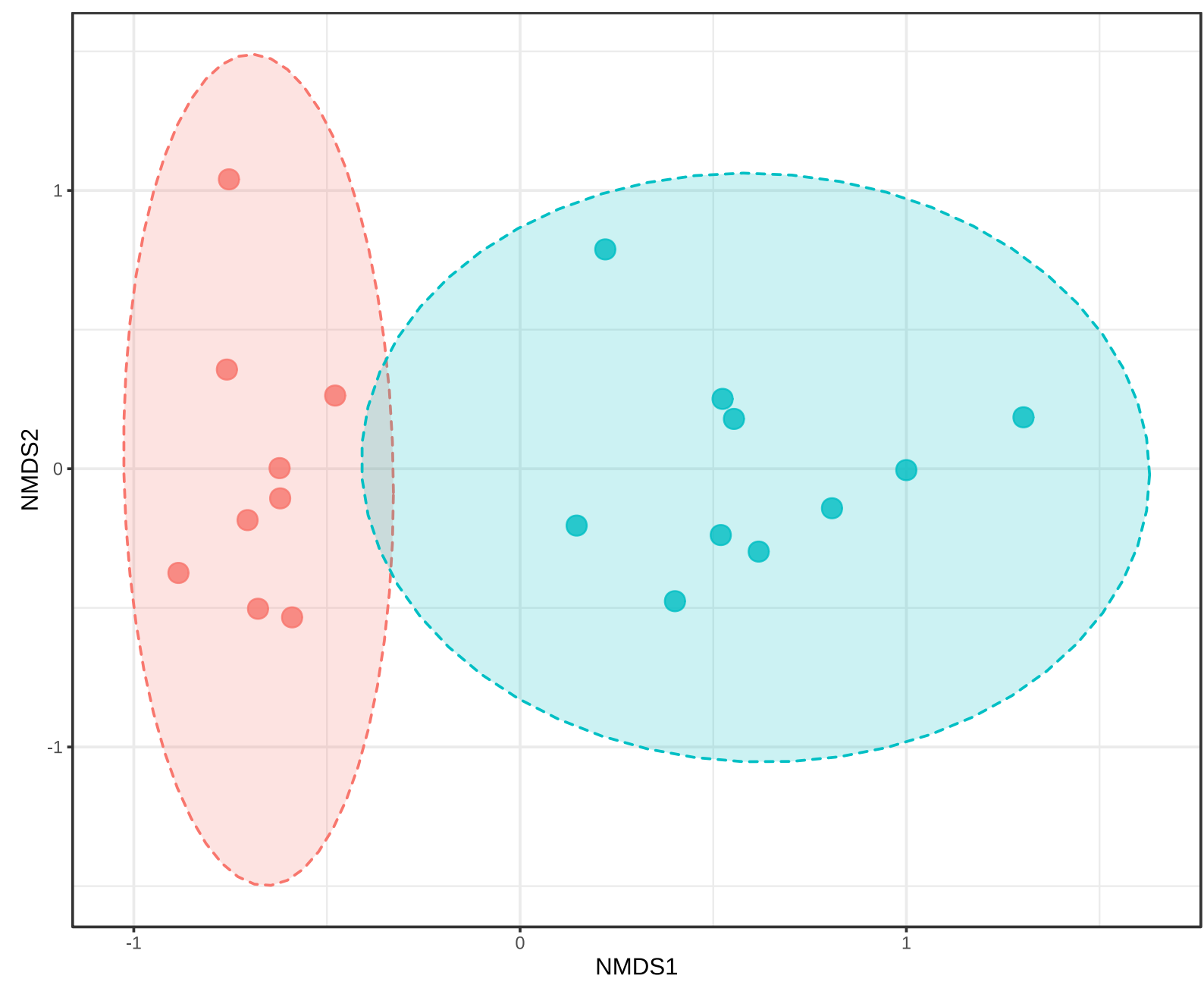

STATUS

Clinically Normal

Diseased

NMDS1 
bioRxiv preprint doi: https://doi.org/10.1101/2020.05.27.120469; this version posted June 18, 2020. The copyright holder for this preprint (which was not certified by peer review) is the author/funder. This article is a US Government work. It is not subject to copyright under 17 USC 105 and is also made available for use under a CCO license.

FIG 4. KEGG metabolism comparison of clinically normal and diseased coral microbiomes. Gene transcription was inferred using Tax4Fun.
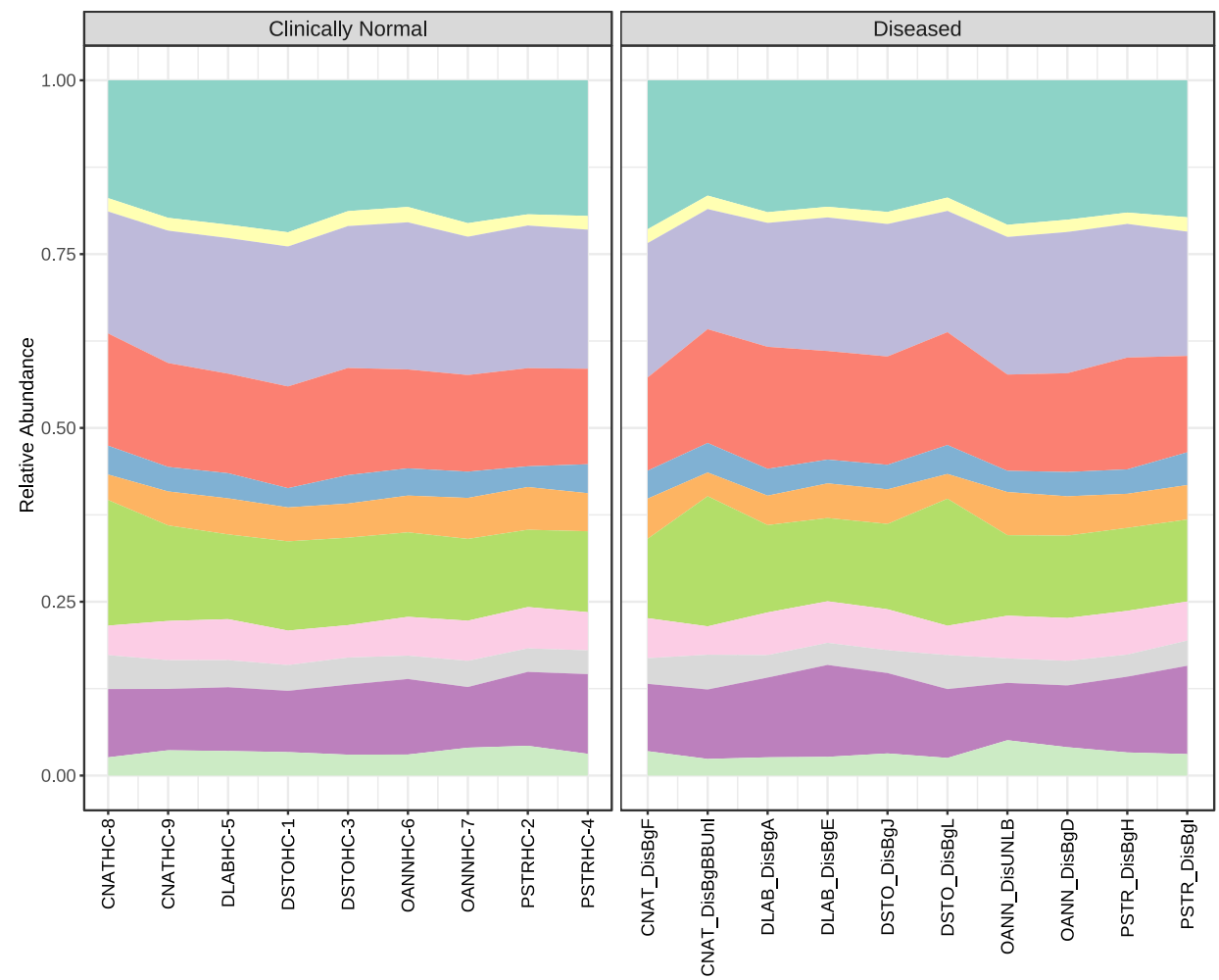

KEGG metabolism

Amino acid metabolism

Biosynthesis of other secondary metabolites

Carbohydrate metabolism

Energy metabolism

Glycan biosynthesis and metabolism

Lipid metabolism

Metabolism of cofactors and vitamins

Metabolism of other amino acids

Metabolism of terpenoids and polyketides

Nucleotide metabolism

Xenobiotics biodegradation and metabolism 